\title{
Artvin Arılı (Demirkapı) Yaylası Kaya Resimleri
}

\author{
Oktay Özgül*
}

\section{$\ddot{\mathbf{O} z}$}

Doğu Karadeniz'de yayla kültürünün yoğun biçimde yaşandığı yerlerden birisi olan Arılı Yaylası/Demirkapı, önemli bir kaya resim alanını barındırır. Benzerlerine Erzurum, Kars, Ardahan, Erzincan, Hakkâri, Ankara, Ordu ve İzmir'de rastladığımız kaya resimlerinin ortak özelliği, göçer kültürlerin günlük hayatlarına dair veriler sunmasıdır. 2019 yllında Kültür ve Turizm Bakanlı̆̆ı’nın izni ile bölgede gerçekleştirdiğgimiz yüzey araştırmalarında Artvin ili, Arhavi ilçesi, Arılı Yaylası'na yakın bir yerde; Namazgâh/Demirkapı adı verilen bir mevkideki kaya resimlerinde çalışmalar gerçekleştirdik. Kaya resimleri üzerinde fotoğraf ve çizim çalışmaları yapılmıştır. Kaya resimleri üzerinde gerçekleştirdiğimiz çalışmalarda, resimlerin göçer kültürler ile ilişkili olduğu ve köklerinin Orta Asya'ya kadar uzandığı anlaşılmıştır. Bu çalışmada; kaya resimlerinin Doğu Anadolu-Kafkasya ve Orta Asya'daki benzerleri ışı̆̆ıda tanıtımları yapılmıştır.

Anahtar Kelimeler: Artvin, Arhavi, Kaya Resimleri, Kafkasya, Orta Asya, Göçer Kültür

\section{Rock Pictures of Artvin Arılı (Demirkapı) Plateau}

\begin{abstract}
Arılı Plateau / Demirkapı, which is one of the places where the plateau culture in the Eastern Black Sea region is intense, has an important rock painting area. The common feature of the rock paintings we encountered also in Erzurum, Kars, Ardahan, Erzincan, Hakkâri, Ankara, Ordu and Izmir is that they provide data on the daily lives of nomadic cultures. In 2019, with the permission of the Ministry of Culture and Tourism, we carried out studies in Artvin province, Arhavi district, near the Arrlı Plateau, we undertook some reasearch on rock paintings at a site called Namazgah/ Demirkapı. Photography and drawing studies on rock paintings were exercised by our team. In the studies we carried out on rock paintings, it was understood that the paintings are related to nomadic cultures and their roots extend to Central Asia. In this study, rock paintings were promoted in the light of their analogues in Eastern Anatolia, the Caucasus and Central Asia.
\end{abstract}

Keywords: Artvin, Arhavi, Rock Paintings, Caucasus, Central Asia, Nomadic Culture

* Doç. Dr., Atatürk Üniversitesi, Edebiyat Fakültesi, Tarih Bölümü, Erzurum/TÜRKIYE, oktay.ozgul@atauni.edu.tr ORCID: 0000-0003-0575-0436

DOI: $10.37879 /$ belleten.2021.781

Makale Gönderim Tarihi: 06.05.2020 - Makale Kabul Tarihi: 16.11.2020

Belleten, Aralık 2021, Cilt: 85/Say1: 304; 781-818 


\section{Giriş}

Demirkapı/Arılı Yaylası kaya resimleri, Artvin ili, Arhavi ilçesinin 20 km, Arılı Yaylası'nın 6,5 km güneybatısında, denizden 2200 m yükseklikte, Namazgâh adı verilen kayalık bir alanda bulunmaktadır (Foto I). Kayalık alanın hemen aşağısından Sarıgöl-Arhavi yayla yolu geçmektedir. Yolun batısı ormanlık olan vadi tabanı ile birleşir. Güneybatı kısmındaki Kaçkar Dağları'nın zirvesi, karlarla kaplı olup, vadi buradan akan kar suları ile beslenmektedir. Vadinin doğu kısmında Kayadibi Yaylası yer almaktadır.

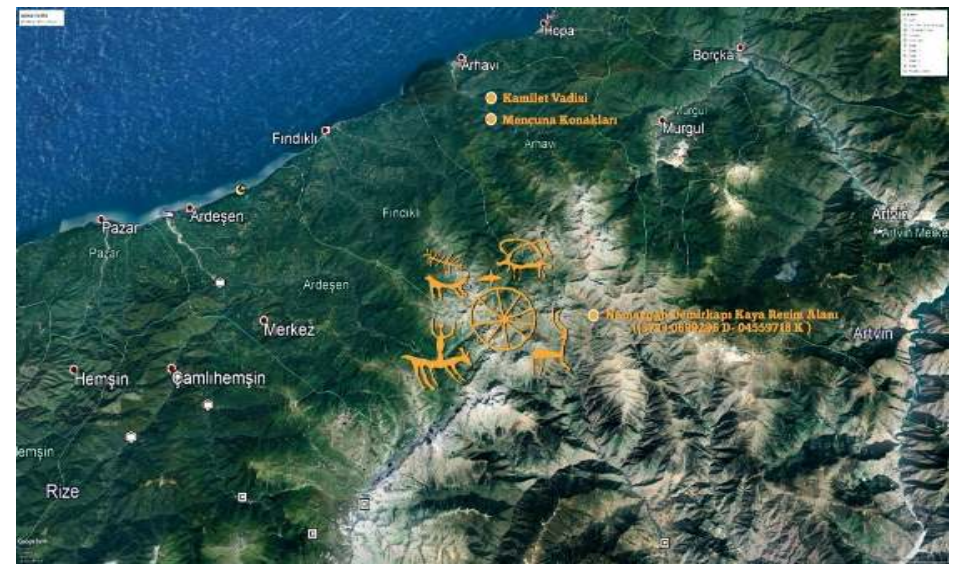

Harita I: Kaya Resim Alanı Uydu Görüntüsü

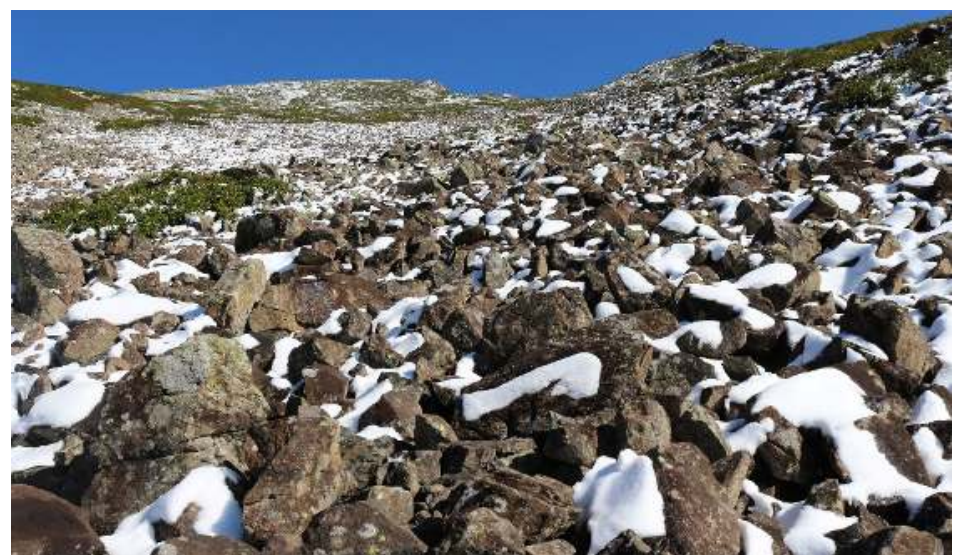

Foto I: Kaya Resim Alanı 
Geçmişten günümüze bölgenin sosyo-ekonomik yapısı hayvancılığa göre şekillenmiştir. Kaya resimlerinin bulunduğu alan, yaylacılık faaliyetlerinin yoğun olarak yapıldığı bir bölgedir. Yerel yol ağları bölgedeki yaylaları birbirine bağlamaktadır. Kafkaslar ile Doğu Karadeniz arasındaki önemli geçiş güzergâhlarından birini oluşturan bölgenin, hemen doğusundaki Kaçkar Dağları'nın zirvelerinden eriyen karların beslediği sular, bugün dahi yaylacılık faaliyetleri için hayati derecede önemlidir. Kaya resimlerinin olduğu bölgenin hem Batum-Gürcistan Kafkasya bağlantısı, hem de Yusufeli-Uzundere-Erzurum yaylalarına bağlantısı, Eski Çă̆’dan itibaren yöredeki göçer kültürlerin yayılım alanının belirlenmesi açısından önemlidir. Orta Asya bağlantılı olduğunu düşündüğümüz göçer kültürlerin yayılım alanlarının tespitine yönelik 2019 yılı çalışmalarımızda Kaçkar Dağları'nın hemen güney yamaçlarında Yaylalar mevkiinde tespit ettiğimiz bağımsız kurgan yapıları, bu yayılımın bölgedeki varlığını ortaya koyar ${ }^{1}$. Göçer toplumların göç güzergâhlarında karşımıza çıkan petroglif alanlarında, kurganların da yer alması kurgan toplumları ile petroglif yapan topluluklar arasında bir bağ olduğunu ortaya koymaktadır. Kazakistan Tamgalısay petroglif alanlarında mezarlıkların olması, Özbekistan Sarmışsay kaya resim alanında birçok kurganın ve sunağın yer alması, yakın bölgemizde ise Kars Digor/Dolaylı kaya resimlerinin olduğu kayalığın hemen üst kısmında pek çok kurganın bulunması bu topluluklar arasındaki bağı açıklamamıza yardımıı olmaktadır².

Demirkapı/Arılı kaya resimleri, bir dă̆ silsilesinden zamanla kopan iri taşların oluşturduğu geniş bir kuşak üzerindedir (Foto II). Petroglifler, bu vadinin $2200 \mathrm{~m}$ ile $2600 \mathrm{~m}$ arasındaki kısmına serpilmiş durumdadır. Bu görüntüsü ile resimlerin olduğu alan Kırgızistan’daki meşhur Saymalıtaş Vadisi’ni andırmaktadır³. 2021

1 Göçer kültürlerin bölge ile bağlantılı olan belirlenmiş yayılım alanları ile ilgili bakn; Alexey E. Rogozhinskiy, "Rock Art Sites in Kazakhstan", Rock Art in Central Asia, Ed. J. Clottes, Paris 2011, s. 13; Augustinová Anna -Stančo Ladislav, "The Petroglyphs of Pashkhurt Valley in the Surkhan Darya Province (South Uzbekistan) - Preliminary Report”, Studıa Hercynıa XX/2, 2016, s. 136. Doğrudan konu ile ilgili olmadığını düşündügümüz için, bu çalışmada kurganlara değinilmemiştir. Başka bir çalışmada, bölgedeki Orta Asya-Kafkasya-Doğu Karadeniz bağlantılı kurganlar hakkında bilgi verilecektir.

2 Rogozhinskiy, agm., s. 13; Augustinová -Stančo, agm., s. 136; Alpaslan Ceylan-Oktay Özgül, “Orta Asya'dan Anadolu’ya Türk Kültürünün Erken Dönem Şifreleri Kaya Resimleri”. 16. Uluslararası Türk Dünyası Sosyal Bilimler Kongresi / 04 - 06 Eylül 2018, İstanbul 2018, s. 68-69.; Eski Türk göçerliğinin yayılım alanı hakkında ayrıntılı bilgi için bkn: Oktay Özgül-Nezahat Ceylan, "Göçerlik ve Yerleşiklik Arasında Bir Bileşen: Fergana Vadisi", Geçmişten Günümüze Türkistan: TarihKültür Ve Medeniyet Sempozyumu, Ankara 2019; s. 472-496; İlhami Durmuş, "Orta Asya'dan Anadolu’ya Türk Konar- Göçer Kültürü”, Orta Asya Türk Kültürünün Anadolu Kültürüne Etkileri Uluslararası Sempozyumu (18-21 Haziran 2019 /Taşkent-Özbekistan), Ankara 2019, s. 11-35.

3 Saymalı Taş, Tengri Dağları’nın Fergana Tarım Havzası’na açıldığı bir bölgede, Fergana dağ sı- 
yılında A. Ceylan başkanlığındaki bir ekiple Saymalıtaş kaya resim alanında çalışma imkânı bulduk. Saymalıtaş kaya resim alanı ile Demirkapı kaya resim alanındaki jeolojik ve morfolojik benzerlik bizleri hayrete düşürmüştür. Yazın bile kar yağışının olduğu yüksek yerlerdeki bu resim alanlarını, sadece jeolojik benzerlik ile açılamak yeterli değildir. Kayalardaki tasvirlerin benzerliği, yapım teknikleri ve tematik sahneler bu iki kaya resim alanındaki öne çıkan diğer benzer noktalardır. Çalışmamıza konu olan kaya resimlerinin benzer örneklerine yakın coğrafyadaki Doğu Anadolu bölgesinde Erzurum ${ }^{4}$, Kars $^{5}, \operatorname{Ardahan}^{6}$ ve Hakkâri'de rastlanır.

rasında bulunan Kögart Dağ Geçidi’nin (ve nehrinin) hemen yanında yer almaktadır. 3500-4000 m yükseklikte ve $7 \mathrm{~km}$ boyunca uzanan vadide, belgelenmiş 10 bin taşın üzerinde yaklaşık 100 bin kaya resmi bulunmaktadır. Erken Tunç Çağı’ndan başlayarak Erken Ortaçağ’a kadar olan süreçte ortaya çıkan kaya resimleri, Avrasya'nın en zengin petroglif alanıdır. Saymalıtaş hakkında ayrıntılı bilgi için bkn: K. Tashbayeva, "Petroglyphs of Kyrgyzstan", Petroglyphs of Central Asia, Ed. K. Tashbayeva, Bishkek 2001, s. 9 vd.; Servet Somuncuoğlu, Saymaltas: Gökyüzü Atlan, İstanbul 2011, s. 31; Anıl Yılmaz, "Saymalıtaş Petrogliflerindeki Toy (Şenlik) Sahneleri Üzerine", Tarih İncelemeleri Dergisi, XXVIII/1, İzmir 2013, s. 223- 248.

4 Alpaslan Ceylan, "Doğu Anadolu'da İlk Türk Yerleşmelerinden Cunni Mağarası", Türkler Ansiklopedisi, C 6, Ankara 2002, s. 425-429; Alpaslan Ceylan, "Erzurum ve Çevresinde Erken Dönem Türk İzleri", Türk Kültuirü, Erzurum 2004, s. 21-50; Alpaslan Ceylan, "Türk Dünyasından Yeni Kaya resimleri", Türk Tarih Kongresi (17/1), 2018, s. 168; Oktay Özgül, "Erzurum Bölgesi Kaya Panoları", Trakya Üniversitesi Edebiyat Fakültesi Dergisi, 5(10), 169-198, 2015, s. 176.; Oktay Özgül, "Erzurum Şenkaya Petrogliflerindeki At Geyik ve Güneş Kursu", Selçuk Üniversitesi Türkiyat Araştırmalan Enstitiisü Dergisi(39), 2016, s. 376 vd.; Alpaslan Geylan-Yavuz Günaşdı, "Türk Bengütaş (Şiveet Ulan)'Daki Oğuz Damgaları İle Cunni Mağarasındaki Damga Ve İşaretlerin Karşılaştırılması", Geçmişten Günümüze Türkistan: Tarih, Kültür ve Medeniyet Sempozyumu, Kazakistan 2019. s. 62.

5 İ. Kılıç Kökten, "1952 Yılında Yaptığım Tarih Öncesi Araştırmalar”, Dil Tarih ve Coğrafya Fakültesi Dergisi XI/2-3-4,1953, s.196; Alpaslan Ceylan, Sarkamıs, Tarihi ve Arkeolojik Araştrrmalar, Ankara 2001, s. 29; Yavuz Günaşdı, "Doğu Anadolu Kaya Resimleri Işığında Doyumlu Kaya Panoları", Selçuk Üniversitesi Türkiyat Araştrmalar Dergisi, S. 39, Konya 2016, s. 391-407; İbrahim Üngör, "Orta Asya'dan Anadolu'ya Kayalara Yazılan Türk Kültürü (Dereiçi Kaya Resimleri)", Selçuk Üniversitesi Türkiyat Araştrmalan Dergisi, , S. 39, Konya 2016, s. 357-370; Mustafa Karageçi, "Borluk Vadisi Erken Demirçağ Mezarı", Kafkas Üniversitesi Sosyal Bilimler Enstitïsü Dergisi, 2016 (Ek Sayı 1) s. 253-265; Nezahat Ceylan, "Yağlıca Kalesi'nde Yılan Figürü ve Türklerde Yılan Simgesi”, Selçuk Üniversitesi Türkiyat Araştrmalan Dergisi, S. 39, Konya 2016, s. 409-421; Akın Bingöl, "Yüzey Araştırmaları Işı̆̆ında Borluk Vadisi Kayaüstü Resimleri”, Selçuk Üniversitesi Türkiyat Araștrmalar Dergisi (39), 2016, s. 347-355; Ceylan, "Türk Dünyasından..." s. 174; Alpaslan Ceylan - Akın Bingöl - Mustafa Karageçi, Eski Çağga Kars Kaleleri, Erzurum 2018, s. 84; Burak Bingöl, Kuzeydoğu Anadolu Petrogliflerindeki Dă̆ Keçisi Motifi, (Yayımlanmamış Yüksek Lisans Tezi). Atatürk Üniversitesi Türkiyat Araştırmaları Enstitüsü, Erzurum 2020, s. 77 vd.

6 Alpaslan Ceylan, "Çıldır Başköy Kaya Resimleri”, Belgü, 2(2), 2015, s. 7 vdd.; Ceylan, "Türk Dünyasından...”, s. 164.; Alpaslan Ceylan-Nezahat Ceylan, Doğunun Sönmeyen Yildrzı Akçakale, Erzurum 2018, s. 138.

7 Wilhelm Freh - Muvaffak Uyanık, "Hakkari-Sat Dağlarında, Gevaruk Vadisi İçinde Bulunan Kaya Resimleri Hakkında Tebliğ", Belleten, C XXI/ S. 84, 1957, s. 619-625; Muvaffak Uyanık,

Belleten, Aralık 2021, Cilt: 85/Sayı: 304; 781-818 
Bununla birlikte Nahcivan ${ }^{8}$, Azerbaycan $^{9}$, Ermenistan $^{10}$ ve Iran $^{11}$, kaya resim sanatının devamlılığı bakımından Orta Asya bozkır kuşağı ile Anadolu arasındaki geçişi sağlarlar. Doğu Anadolu başta olmak üzere Doğu Karadeniz Bölgesi’nde yer alan kaya resim alanları hakkında kesin bir kronoloji olmamakla birlikte, Paleolitik Çă̆'dan başlayıp Erken Demir Çă̆'a kadar yapıldıkları konusunda çeşitli çalışmalar vardır ${ }^{12}$.

Demirkapı/Arılı Yaylası kaya resimleri ilk kez O. Hacıoğlu tarafindan kamuoyuna duyurulmuş, fakat detaylı bilimsel çalışmalar yapılmamıştır ${ }^{13} .2019$ yılında başkanlığımda gerçekleştirdiğimiz "Artvin İli ve İlçeleri Yüzey Araştırmaları" kapsamında

Petroglyphs of South - Eastern Anatolia, Akademische Druck und Verlagsanstalt, Graz 1974, s. 32 vd.; Hale Tümer, Van-Hakkari Dağllk Bölgesi Kaya Resimleri, İstanbul Üniversitesi Sosyal Bilimler Enstitüsü, İstanbul 2017, s. 45-125.

8 Veli Baxşeliyev, Gamikaya Tasvirleri, Bakü 2003, s. 76 vd.; T. Xelilov, Gemigaya Etrafinda Aexeoloji Tedgigatlar, Nahcican 2018, s. 9 vd.

9 Namazoğlu Caferqulu - Firuze Muradova - Memmedrza qızı, Gobustan Petroglifleri, Bakü 2003, s. 90vd.; Servet Somuncuoğlu, Sibirya'dan Anadolu'ya Tasstaki Türkler, İstanbul 2008: s. 436; Melahet Ferecova, Azerbaycan Qayaüstï İnceseneti, Bakü 2009, s. 20 vd.; Kudret İsmailzade, "Gobustan Açı Hava Müzesi”, IRS, 3(11), 2014, s. 6 vd.

10 Ermenistan'ın Geghama, Aragatz bölgesindeki kaya resimlerini Ermeni bilim adamları farklı şekillerde yorumlayıp, tartışmalı "vishaps" taşlardaki resimler ile benzerliklerini ortaya koymaya çalışalar da, bu bölgedeki kaya resimleri, Tunç Çă̆gnda Orta Asya’nın muhtelif yerlerinde ortaya çıan kaya resimleri ile örtüşmektedir. Stilize edilmiş geyik resmi, dağ keçisi tasvirleri, av ve tuzak sahnelerindeki kompozisyonlar, hareketli hayvan tasvirlerinin yer aldığı kaya resimleri, erken dönem Türk kaya resim geleneğinin bölgedeki devamından başka bir şey değildir. Özellikle bazalt kayalıklar üzerindeki güneş sembolleri ve abartılı hayvan betimlemeleri, Kazakistan Tamgalısay ve Saymalıtaş’ı anımsatır. Ermenistan Tunç Dönemi kaya resimleri hakkında bk. Karen Tokhatyan, "Rock Carvings of Armenia", Fundamental Armenology, No. 2, 2015, s. 184 -185-186 vd.

11 A. Ceylan başkanlığında 2008 yılında Ahar yakınlarındaki Meşginşahr'da kaya resim alanında incelemelerde bulunduk. İran'daki kaya resimleri ile ilgili çalışmamız yayın aşamasındadır.

12 İ. Kılıç Kökten, "Yazılıkaya'da ve Kurbanağa Mağarasında (Kars-Çamuşlu) Yeni Bulunan Dip Tarih Resimleri", Karseli 6/69, Ankara 1970, s. 2 vd.; Oktay Belli, "New light on the Earliest Art of Anatolia: Kızların Mağarası (The Cave of the Maidens)", Turkish Treasures 2, İstanbul 1978, s. 28 vd.; Haşim Karpuz, "Çamuşlu'da Yontma Taş Çağı Kaya Resimleri”, TÜBİTAK Bilim ve Teknik 10/212, Ankara 1977, s. 2; Tümer, "Van-Hakkari Dağlk Bölgesi....” s. 64; Ceylan, "Türk Dünyasindan...", s. 162 vd.

13 O.Hacioğlu-2014;http://werere.patikaa.com/anadolu-ve-kafkas-cografyasinda bulunan en-eski-petroglif/; Hacıŏglu bu vb. haberlerinde bölgede yüzden fazla kaya resmi ve damganın olduğunu ifade etmiştir. Ancak 2019 yılında yapmış olduğumuz yüzey araştırmalarında bahsedilen kadar resimli taş bulamadık. Muhtemelen ya yerleri değişmiş ya da tahribata uğradığı için yok olmuştur. 
yaptığımız çalışmalarda, 11 adet kaya üzerinde 56 adet çeşitli konuları içeren resim tespit edilmiş, fotoğraflama ve çizim çalışmaları tarafimızdan yapılmıştır ${ }^{14}$.

Resimlerin olduğu kaya yüzeylerinin, yağmur, kar ve doğal sebeplerden ötürü parçalandığ1 ve kaya yüzeylerinde çatlakların olduğu görülmüştür. Kaya resimlerini daha sistematik bir biçimde belgelemek için her bir taşa ayrı numara verdik ve çizimleri yaparken her kayanın üzerindeki resimleri de ayrı şekilde numaralandırdık. Bu şekilde sonraki yıllarda belki de yer değiştirecek olan başka resimleri bulduğumuz zaman, karışıklık olmayacağını düşündük.

Kaya resimlerindeki tasvirlerin bir kısmının kazıma/vurma tekniği ile bir kısmının ise gagalama (pecket) yöntemi ile yapıldı̆̆ı anlaşılmıştır. Kaya resimlerinde dağ keçisi motifi, hareket halinde yapılmış abartılı boynuzlu geyikler, av ve tuzak sahneleri, güneş kursu ve süvarilerden oluşan çeşitli kompozisyonlar yer alır. Ayrıca örneğine daha önce Anadolu'da rastlamadığımız özenle çizilmiş olan balık resimleri de ayrı bir yer tutar.

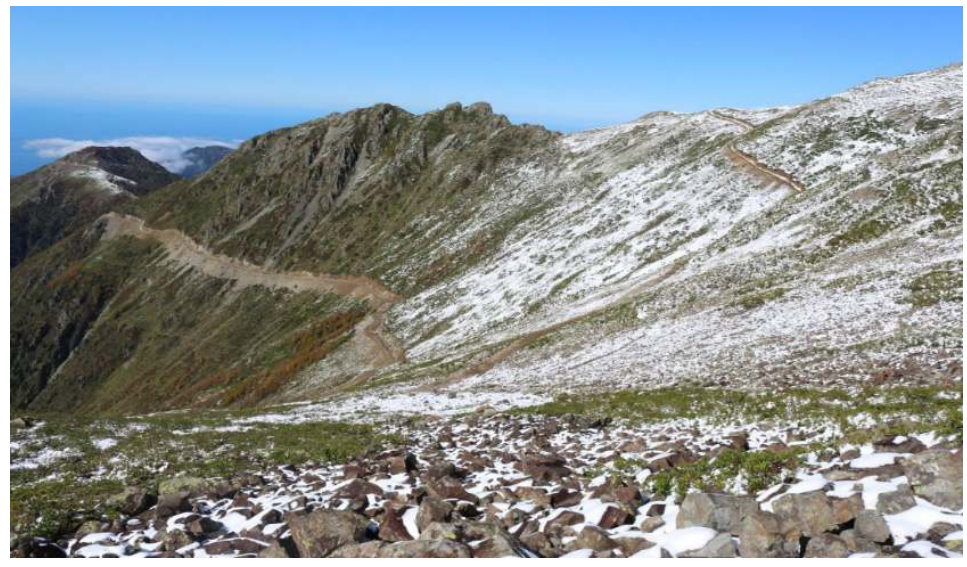

Foto II: Kaya Resim Alanı ve Ulaşım Ağı

14 Kültür ve Turizm Bakanlığı'nın 94949537-161.01-.736359 sayı ve 09.09.2019 tarihli izinleri ile başkanlığımdaki bir ekiple yürütülen yüzey araştırması 17-25 Eylül 2019 tarihleri arasında, Artvin-Yusefeli, Alanbaşı Mah. Çeltikdüzü Mah. Olgunlar Mah., Öğdem Mah., Düzler Mevkii, Arhavi Arılı Mah./Namazgâh Tepe Mevkii’nde gerçekleştirilmiştir. Desteklerinden dolayı Kültür ve Turizm Bakanlığı ve Türk Tarih Kurumu’na teşekkür ederiz. Çalışmalarımız sırasında yöre halkından bize rehberlik eden Sayın Cengiz Velimahmutoğlu ve Coşkun Hekimoğlu'na; ayrıca arazi çalışmalarına katılan Arş. Gör. Beyazıt Söylemez ve Arş. Gör. Burak Bingöl ile Bakanlık temsilcisi Erkan Tunç'a teşekkürü bir borç biliriz. Bunun yanı sıra Yusufeli Belediye Başkanı Sayın Eyüp Aytekin'e de yardımlarından dolayı şükranlarımızı sunarız. 
Kaya Üzerindeki Figürler ve Anlamlandırılması: Kaya resimlerinin bulunduğu alan hem denize hem de yayla kültürüne açık bir yer olma özelliği taşıdığı için bu iki yaşama dair mistik veriler sunmaktadır.

I No.lu Kaya: Demirkapı/Arılı mevki kaya resimlerinin en yaygin olduğu ana kaya kütlesinin boyu $1.80 \mathrm{~cm}$ genişliği ise $1.70 \mathrm{~cm}$ 'dir. Kayanın alt kısmında başka bir yerden koparak gelmiş bir kaya parçası yer almaktadır. Petrogliflerin kaya kırılmadan önce yapıldığı anlaşılmaktadır. Kayalık alanın durumuna göre pastoral hayatın işlenmiş olduğu sahneler daha çok I no.lu kayanın üst kısmında toplanmıştır. Kaya üzerinde 25 adet figür yer almaktadır. Figürler, aynı elden ve vurma/ kazıma tekniği ile yapılmıştır (Foto III-Çizim I-II-III-IV).

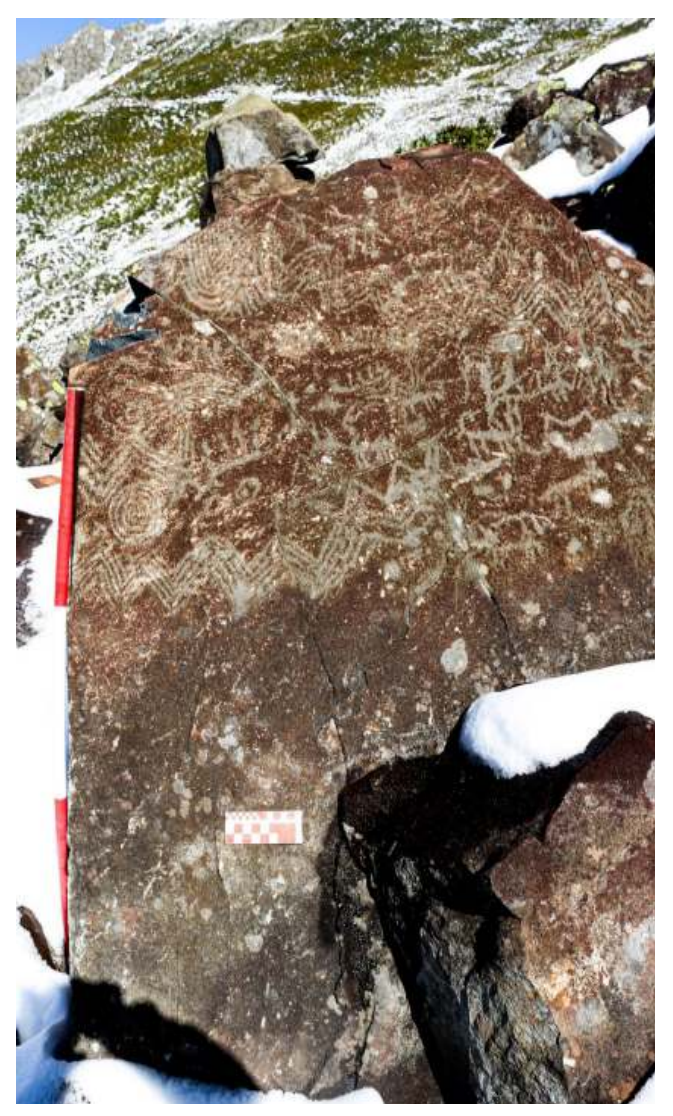

Foto III: I No.lu Kaya 


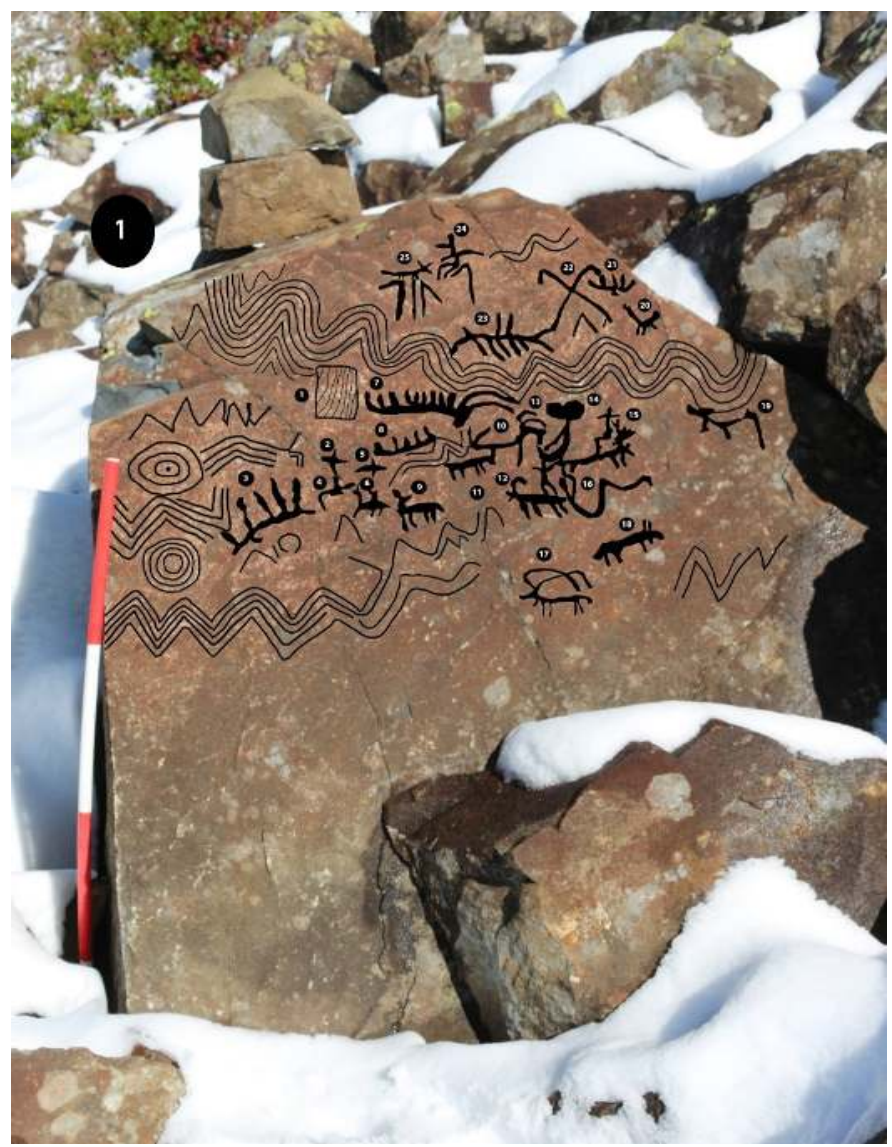

Çizim I: I No.lu Kaya

I No.lu kayada çizilmiş zikzaklar ve çeşitli figürler, bölge coğrafyasının resmedilmesinden başka bir şey değildir. Dağlar, yollar, tepeler, dereler, detaylı bir şekilde adeta bir ressamın tualine işlediği gibi kayaya işlenmiştir. I no.lu kaya üzerindeki resimleri iki şekilde anlamlandırdık: Birincisi, burasının tören sahnelerinden birkaç örneği barındırdığı için bir kült alanı/tören yeri olduğu yönündedir. İkincisi ise, burada yaşayan insanların günlük hayatlarını resmettikleri bir çeşit yurt/yaşam yerinin merkezi olduğu yönündedir. 


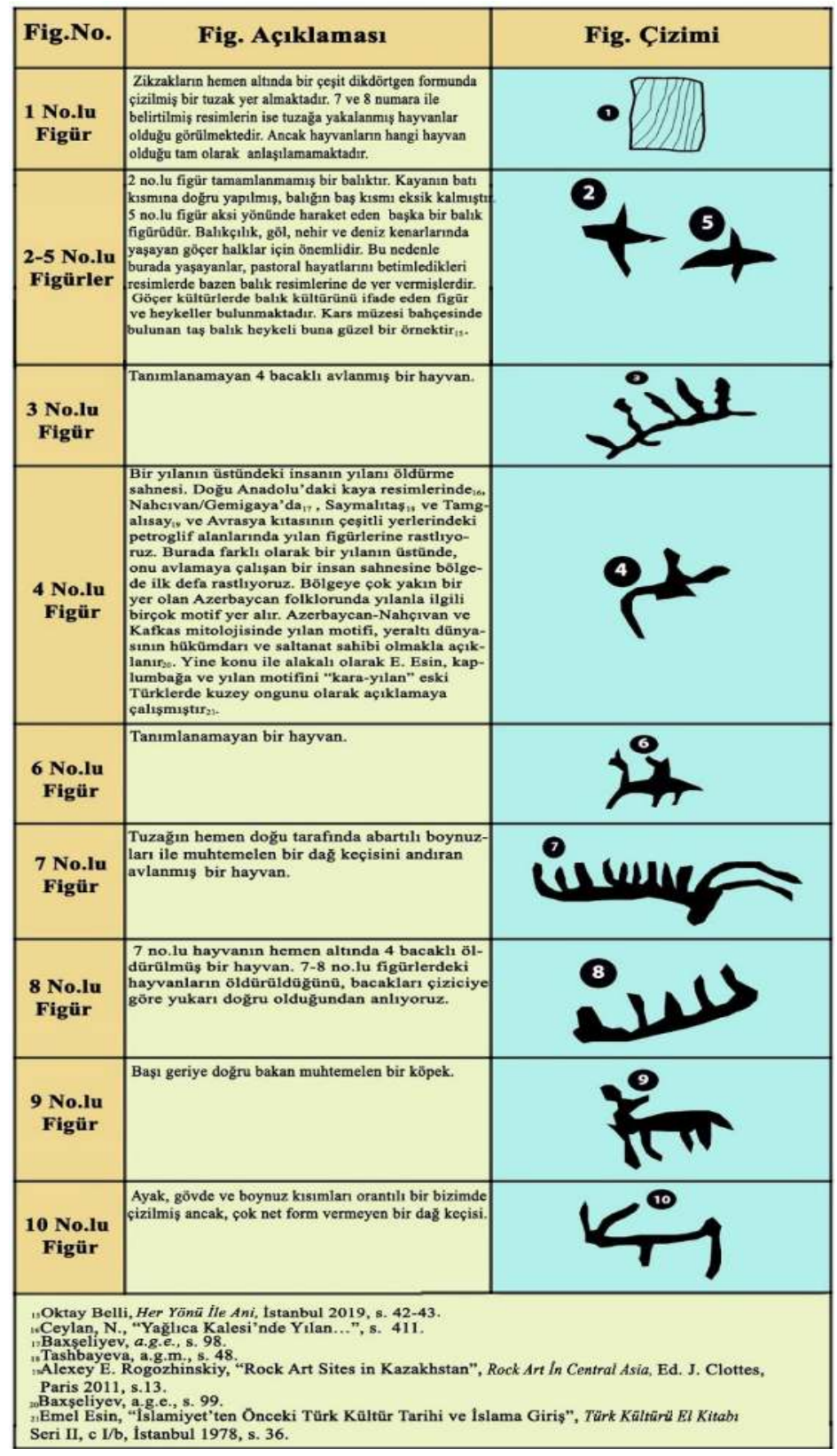

Çizim II: I No.lu Kaya 


\begin{tabular}{|c|c|c|}
\hline Fig. No. & Fig. Açıklaması & Fig. Çizimi \\
\hline $\begin{array}{l}11 \text { No.lu } \\
\text { Figür }\end{array}$ & $\begin{array}{l}\text { Boynuzu } 10 \text { no.lu dă̆ keçisinin ayağı ile bütünleş- } \\
\text { miş halde tasvir edilmiş bir dağ keçisi. }\end{array}$ & \\
\hline $\begin{array}{l}12 \text { No.lu } \\
\text { Figür }\end{array}$ & \begin{tabular}{|l|} 
Dağ keçisinin üstünde ellerini iki yana açmıș, arka \\
ayağı hafif kalkmış bir insan figürü (ritüel sahnesi). \\
Bu tür ritüel sahneleri, hayvanın üzerindeki insanın \\
dünyalar arasındaki gezintisini ifade eder. Bazen bu \\
hayvan, bir at olabileceği gibi, bazen bir geyik, \\
bazen de bir dağ keçisi olur. Bu tür sahnelere Say- \\
malıtaş'ın Tunç Devri petrogliflerinde, Sibirya kaya \\
resimlerinde, Colpan-Ata kaya resimlerde,Anadolu'da \\
ise Karaboncuk ve Digor kaya resimlerinde rastlamak \\
mümkündür.
\end{tabular} & 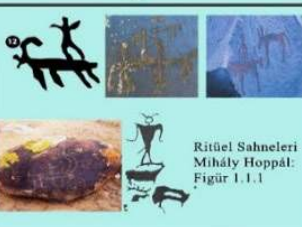 \\
\hline $\begin{array}{l}13 \text { No.lu } \\
\text { Figür }\end{array}$ & $\begin{array}{l}\text { Baş kısmı tahrip olmuş bir dağ keçisi. Dağ keçisi- } \\
\text { nin ön ayakları, } 10 \text { numaralı dağ keçisinin arka } \\
\text { kısmı ile bütünleşmiş bir şekilde çizilmiştir. Dağ ke- } \\
\text { cisinin boynuzları orantısız bir biçimde ve neredey- } \\
\text { se arka ayaklar ile birleştirilmiş bir şekilde tasvir } \\
\text { edilmiştir. }\end{array}$ & \\
\hline $\begin{array}{l}\text { 14-15No.lu } \\
\text { Figür }\end{array}$ & $\begin{array}{l}14 \text { no.lu resim, ne olduğu tam olarak tanımlanama- } \\
\text { yan bir hayvan üzerinde iki kolu açı şekilde şemati- } \\
\text { ze edilmiş bir insan figürüdür. } 15 \text { no.lu figür ise net } \\
\text { olmamakla birlikte boynuzlu bir geyik üzerinde ant- } \\
\text { ropomorfik bir şekilde şematize edilmiştir. }\end{array}$ & \\
\hline $\begin{array}{l}16 \text { No.lu } \\
\text { Figür }\end{array}$ & $\begin{array}{l}16 \text { no.lu figürde çaresizce yerde uzanmış doğrulma- } \\
\text { ya çalıșan bir insanın, yılan tarafından ısırılma sah- } \\
\text { nesi tasvir edilmiştir. }\end{array}$ & \\
\hline $\begin{array}{l}17 \text { No.lu } \\
\text { Figür }\end{array}$ & 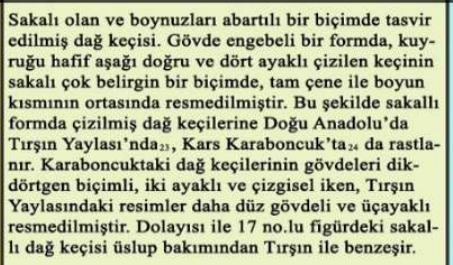 & (Tümer 2011:82) \\
\hline $\begin{array}{l}18 \text { No.lu } \\
\text { Figür }\end{array}$ & $\begin{array}{l}\text { Boynuzları kırık, ön sol ayağı diğerinden kısa ve } \\
\text { kuyruk kısmı çok kalın bir şekilde çizilmiş olan bir } \\
\text { bizon }_{25} \text {. }\end{array}$ & \\
\hline $\begin{array}{l}19 \text { No.lu } \\
\text { Figür }\end{array}$ & $\begin{array}{l}\text { Anlamlandırilamayan bir hayvan. Muhtemelen ant- } \\
\text { ropomorfik görünümlü bir canlı ve zoomorfik (yılan) } \\
\text { bir canlının mücadelesi gibi durmaktadır. }\end{array}$ & \\
\hline \multicolumn{3}{|c|}{ 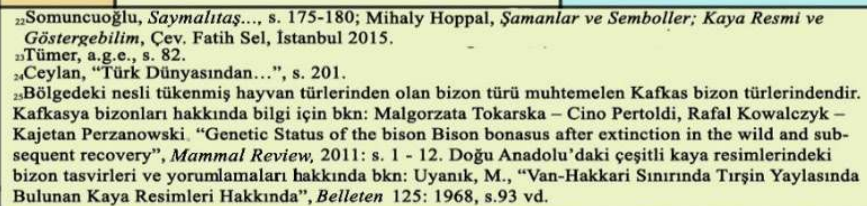 } \\
\hline
\end{tabular}

Çizim III: I No.lu Kaya 


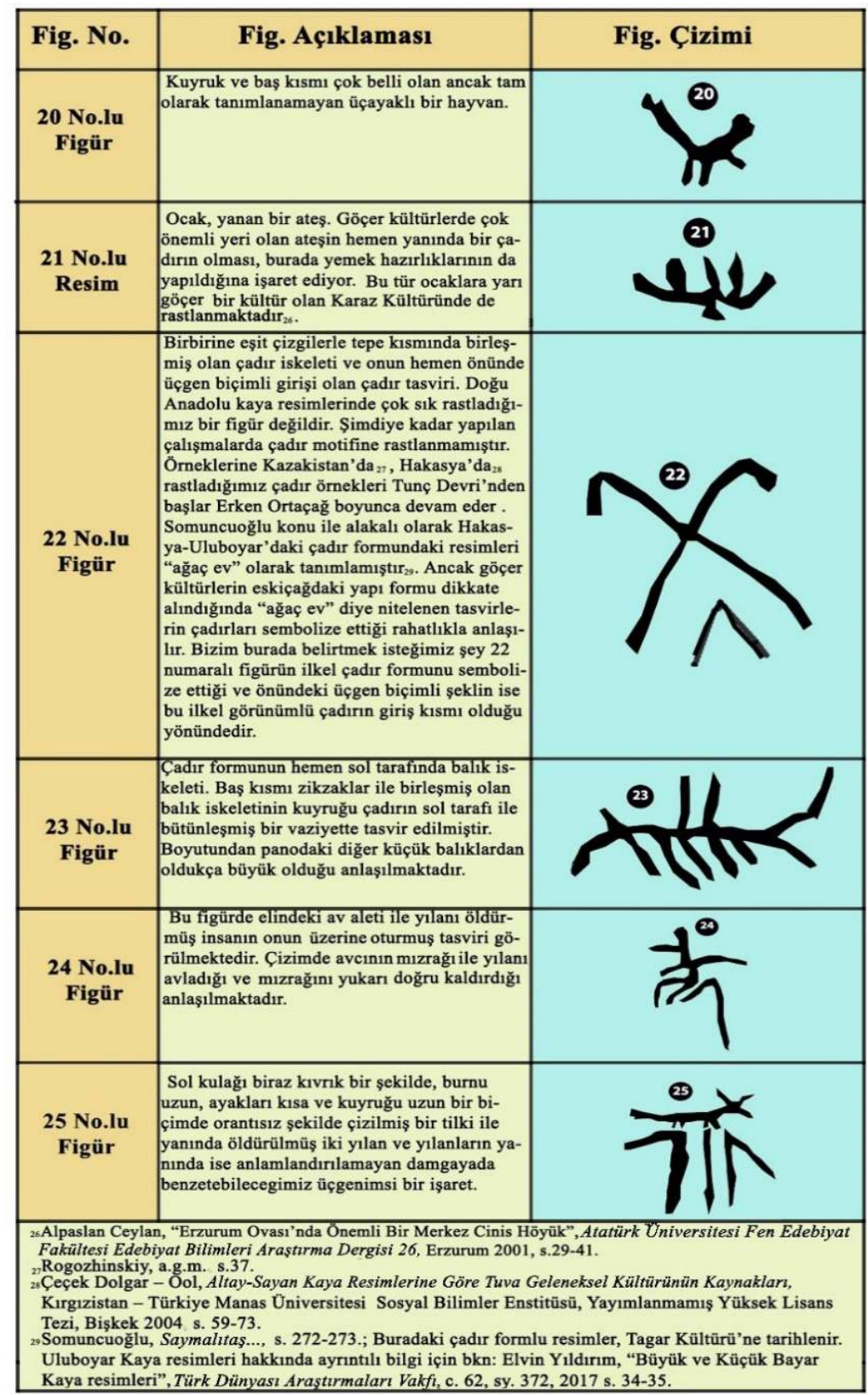

Çizim IV: I No.lu Kaya 
I No.lu Panonun Yorumu: Yukarıda da ifade ettiğimiz gibi panoda 25 adet resim yer almaktadır. Pano genel itibari ile çok fazla tahribata uğradığı için bazı resimler tam olarak anlaşılamamaktadır. Kaya resim alanı yaylacılığa uygun bir bölge olduğu için, panoda daha çok pastoral bir hayat anlatılmaya çalışllmıştır. Bunun yanında resimde çevre bölgelerdeki petrogliflerde rastlamadığımız balık motifi de ön plana çıkmaktadır. 2-5 numaralı balıkların yüzer halde resmedildiği, 23 numaralı balığın ise daha büyük ve öldürülmüş olduğu göze çarpmaktadır. Bunun yanında yine panodaki 12 no.lu figürdeki şaman ayini sahnesi de dikkati çekmektedir. Bu sahne, Arılı resimlerinin köken konusuna sağlam bir delil olabilecek özellik göstermektedir. Dă̆ keçisinin üstünde ellerini iki yana açmış, dünyalar arasında yolculuk yapan şaman tasviri, Avrasya kıtası petrogliflerinde sıkça rastlanan bir figürdür ${ }^{15}$. Zikzaklar, kayayı üç parçaya ayırmış gibidir. Bu zikzakların bölgeye ulaşan yolları ve dağları simgelediğini tahmin etmekteyiz ki; kaya resim alanının topoğrafik yapısı da bu durumu doğrulamaktadır. Zikzakların arasında kalmış labirente benzeyen dairelerden oluşmuş şekiller de, panodaki sahneyi ilginç hale getirmektedir. Bu şekillerin neye benzediği konusunda net bir şey söylemek mümkün olmamakla birlikte, oba büyükleri için yapılmış kurgan olma ihtimalleri vardir.

II No.lu Kaya: 2 no.lu kaya üzerinde 4 adet figür yer almaktadır. 1 no.lu figür tam olarak anlamlandırılamamaktadır. 2 no.lu figür, kanatları orantısız bir biçimde yapılmış bir kuştur. 3 no.lu resim yılanın üzerinde çizilmiş kafası olmayan antropomorfik bir figür, 4 no.lu resim ise mantar şapkalı antropomorfik bir figürdür (Foto IV-Çizim V).

15 Vladimir Dmitrievich Kubarev-D. Tseveendorj-Esther Jacobson, Petroglyphes Of Tsagaan-Salaa And Baga-Orgur 2005 Russia s. 343, Figür;833; Somuncuoğlu, Gökyüzü Atlar, s. 175. 
Artvin Arılı (Demirkapı) Yaylası Kaya Resimleri

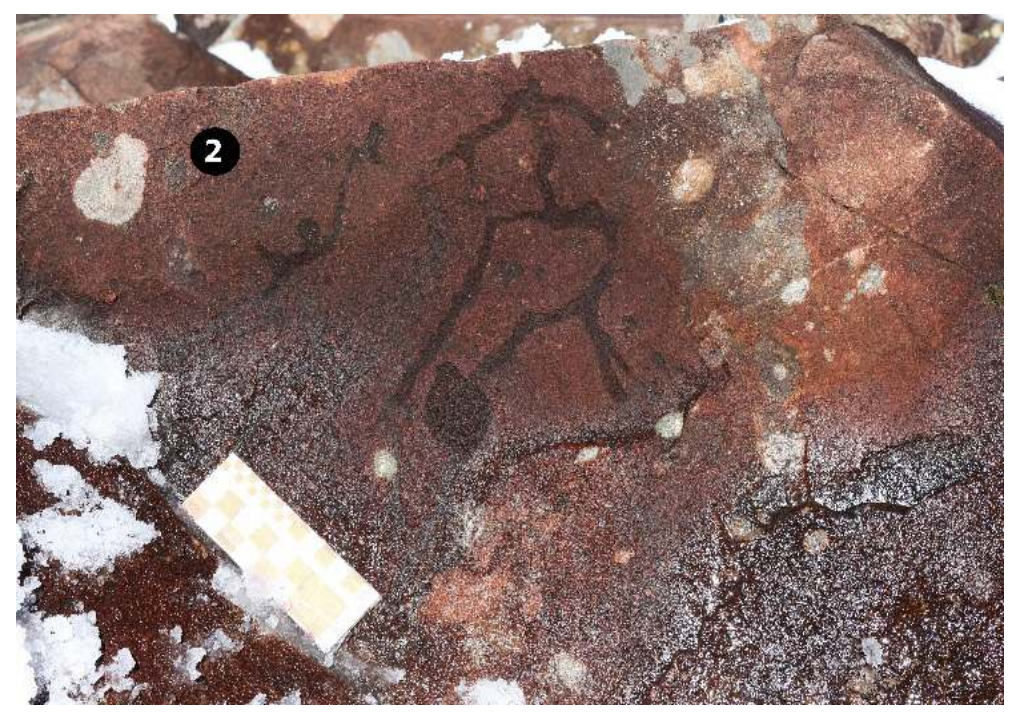

Foto IV: II No.lu Kaya

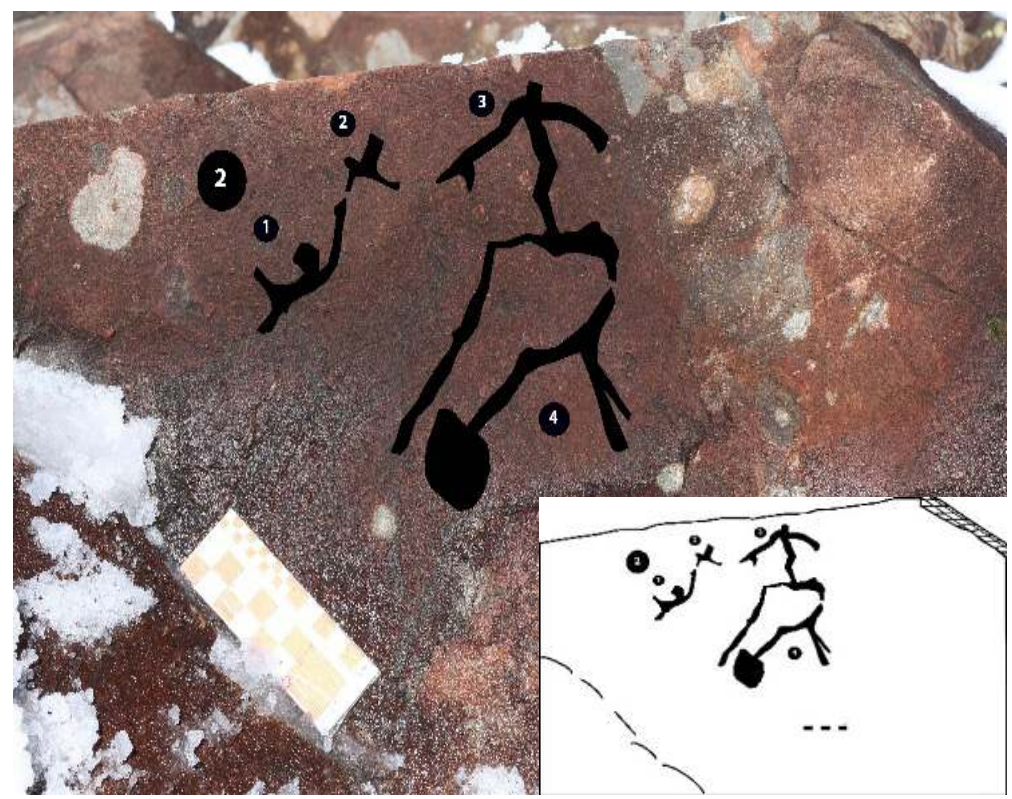

Çizim V: II No.lu Kayanın Çizimi 
III No.lu Kaya: 3 no.lu kaya 1 no.lu kayanın 20 m aşağısındadır. Kaya yuvarlanmanın etkisi ile deforme olmuştur. Kaya üzerinde 5 adet figür tespit edilmiştir. Büyük çoğunluğu geyiklerden oluşan kayanın yüzeyi oldukça tahrip olmuştur. 1 no.lu resimdeki geyiğin boynuzları arkaya doğru ve gövde ile orantılı bir biçimde çizilmiştir. Çizgi tekniğinde profilden çizilen geyiğin ön iki ayağı ileriye doğru korkar bir şekilde hamle yapar gibidir. 2 no.lu geyiğin boynuzu daha kısa ve dikine çizilmiştir. Ön ayakları 1 no.lu resimden daha uzun olan geyik, tıpkı 1 numaralı resimde olduğu gibi ileri doğru ürkek bir hamle içerisinde gibidir. 3 no.lu geyiğin diğer ikisine nazaran daha orantısız olduğu, arka ve ön ayaklar arasında bu orantısızlığın daha fazla olduğu görülür. Ön bacaklar daha zayıf, arka ayaklar ise daha kalın çizilmiştir. Boynuzlar ileriye doğrudur. 4 no.lu resim, 3 no.lu geyiğin altında muhtemelen ressam tarafindan cepheden çizildiği için ölü vaziyette ve ayakları yukarı doğru olan bir hayvana benzetilmiştir. 5 no.lu resim ise muhtemelen kırık bir ağaç parçasına benzemektedir (Foto V-Çizim VI-VII).

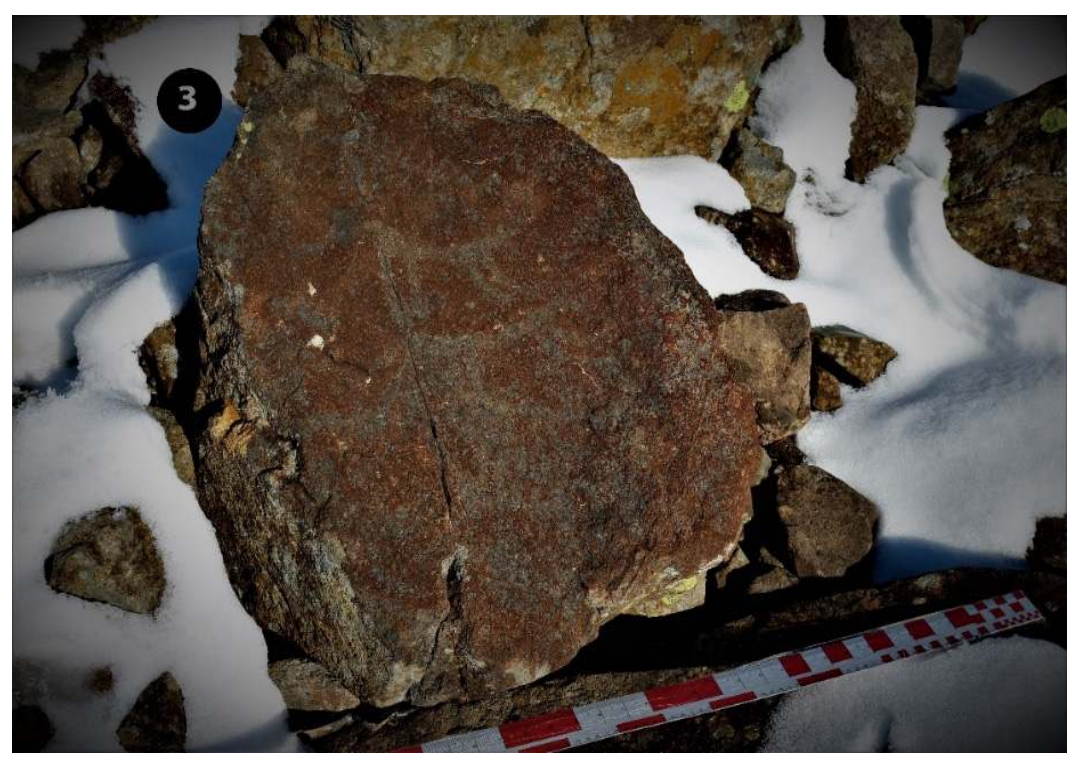

Foto V: III. No.lu Kaya 
Artvin Arılı (Demirkapı) Yaylası Kaya Resimleri

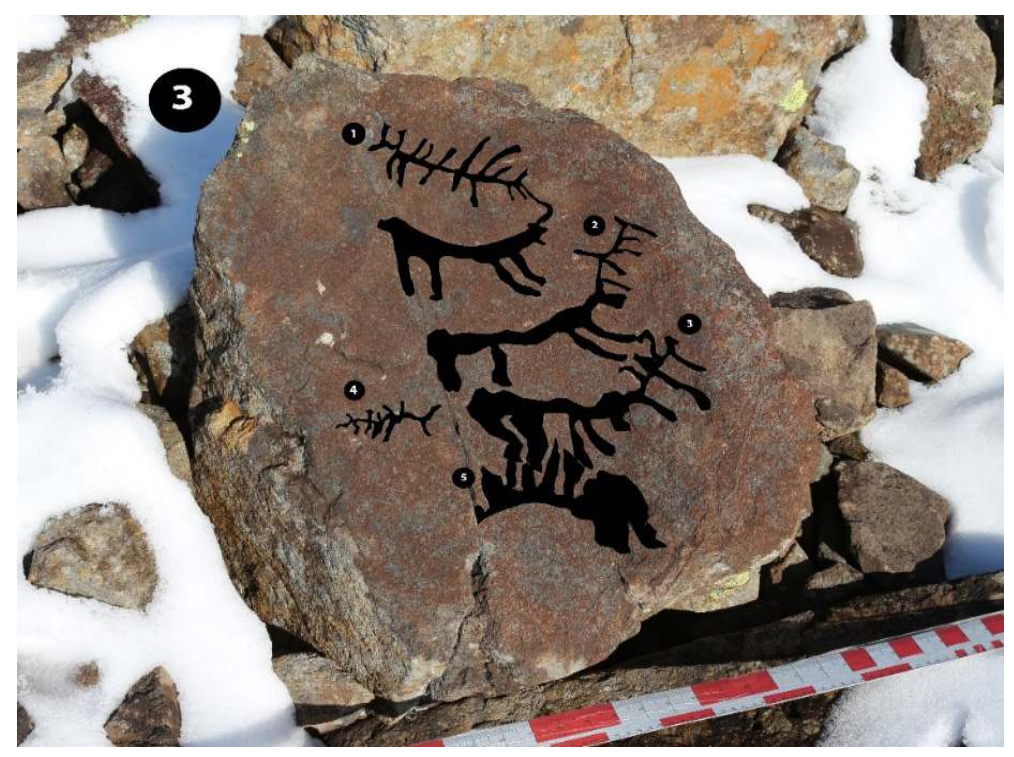

Çizim VI: III. No.lu Kayanın Çizimi

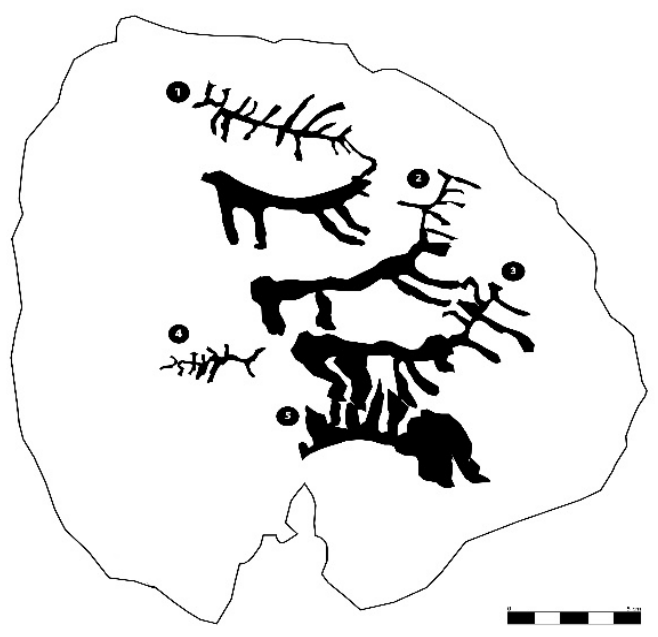

Ģizim VII: III. No.lu Kayanın Çizimi 
IV No.lu Balıklı Kaya: 7 no.lu kayanın hemen 10 m aşağısında alt tarafi kırık 60x130 cm boyutundaki bir kaya üzerinde 9 adet figür tespit edilmiştir. Kaya üzerindeki figürler, Anadolu'da daha önce hiç karşılaşmadığımız bir kompozisyon içermektedir. Kaya üzerinde 7 adet balık ve iki adet sandal/kayık figürü yer almaktadır. Balıklardan 6'sı batıya doğru hareket ederken çizilmiş, 9 numaralı balık ise aksi yönde çizilmiştir. Balıklardan 6 numara ile belirtilen olan en büyük; 5 numara ile belirtilen ise en küçük olanıdır. Balıkların tamamı yüzgeçli ve hemen hepsi yüzerken resmedilmiştir. 7-8 numarada belirtilen çizimde sandallar içinde 4'er insan tasvir edilmiştir. Bu kayada balık avı sahnelenmiş olmalıdır (Foto VI-Çizim VIII-IX).

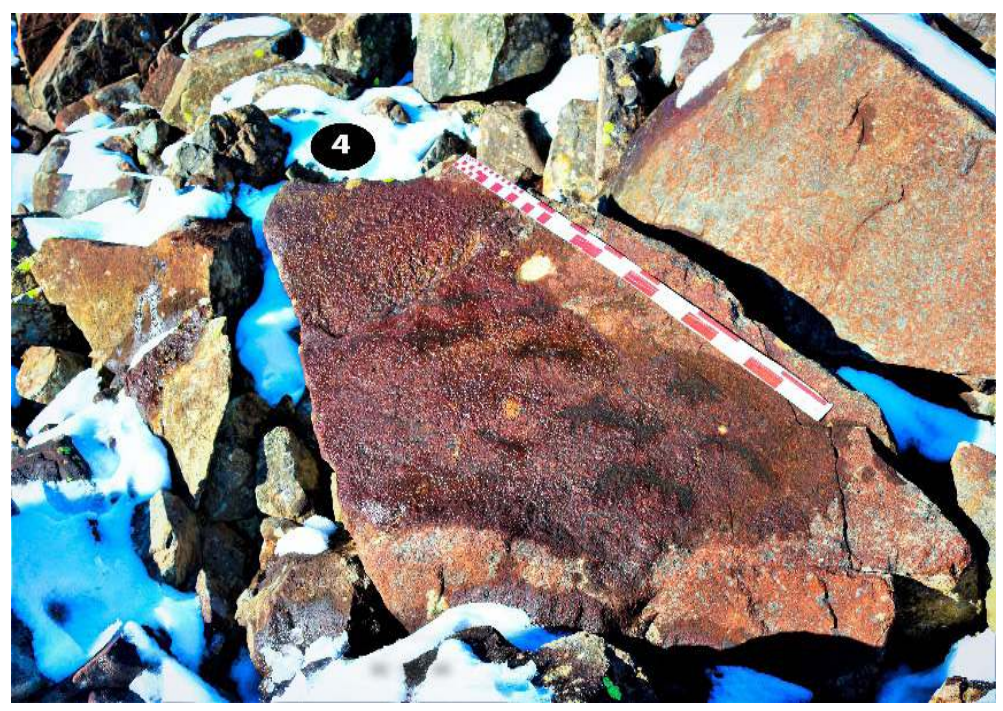

Foto VI: IV. No.lu Balıklı Kaya 


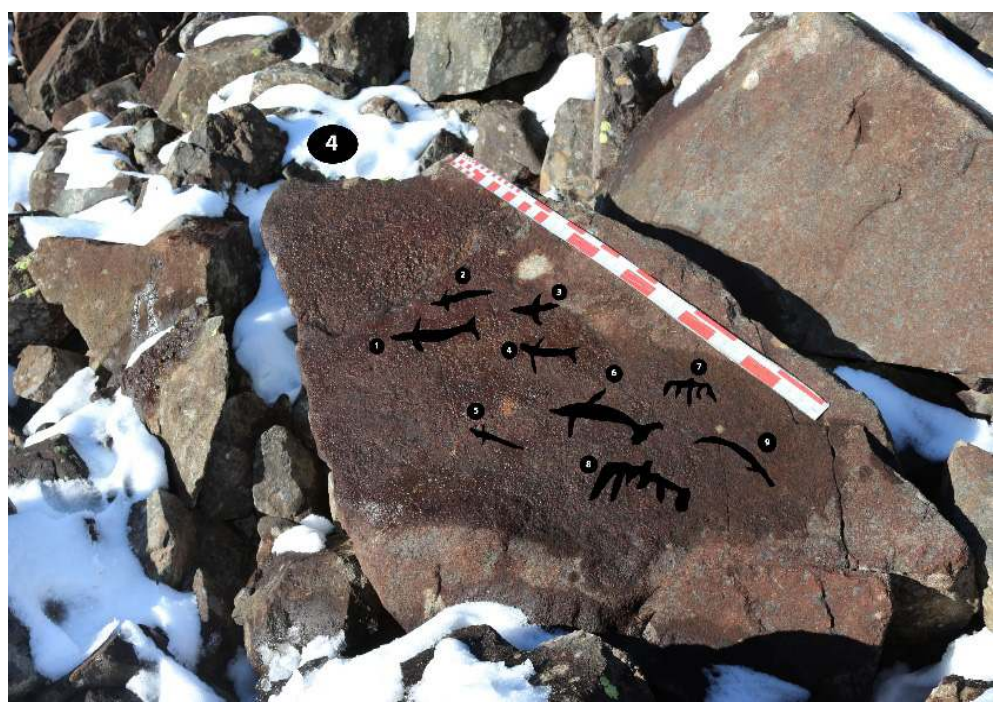

Çizim VIII: IV. No.lu Balıklı Kayanın Çizimi

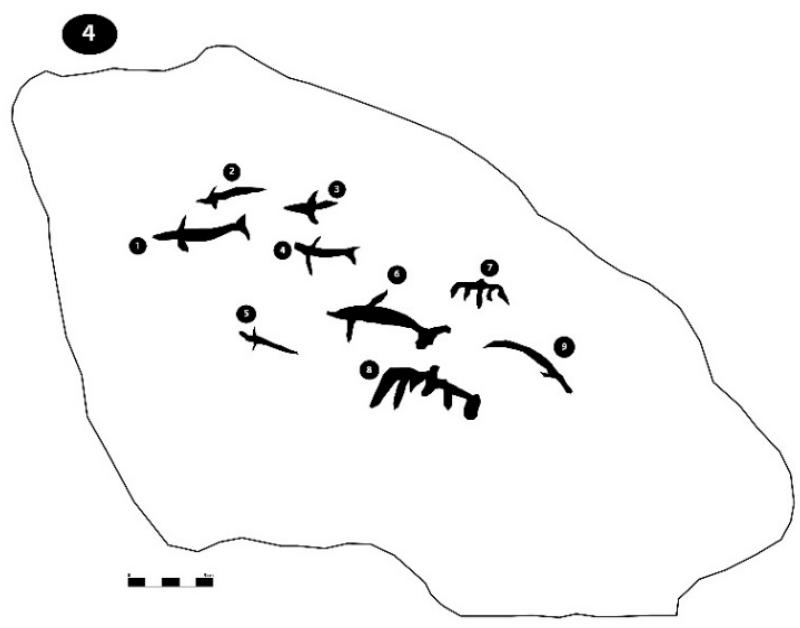

Çizim IX: IV. No.lu Balıklı Kayanın Çizimi 
V No.lu Kaya: 10 no.lu kayanın 5 m kadar batı tarafinda bir sandal/kayık ve hemen onun altında kulakları yukarı doğru dik bir biçimde tasvir edilmiş, kuyruğu dik ve ön ayaklardan sağdaki biraz kısa çizilmiş bir yaban eşeği yer almaktadır. Sandalın içinde insanları tasvir etmek için baştan birinci ve sondaki figürler oldukça belirgin bir biçimde çizilmiştir. Bu şekilde içinde insan taşıyan sandal figürlerine Sibirya'nın bazı yerlerinde de rastlanır ${ }^{16}$ (Foto VII).

Kimi araştırmacılar üstlerinde insan bulunan mavna tasvirlerinin, yeraltının ya da ölüler dünyasının cisimleşmiş hali olan büyük bir elk figürünün yanında yer buldukların ifade ederler. Hoppal'a göre bu gemiler ya da sandallar ölülerin ruhlarını öteki dünyaya götüren sembollerdir ${ }^{17}$ (Çizim X-XI). V No.lu kayada da kayık, yabani bir eşekle tasvir edilmiştir (Foto VIII-Çizim XII).

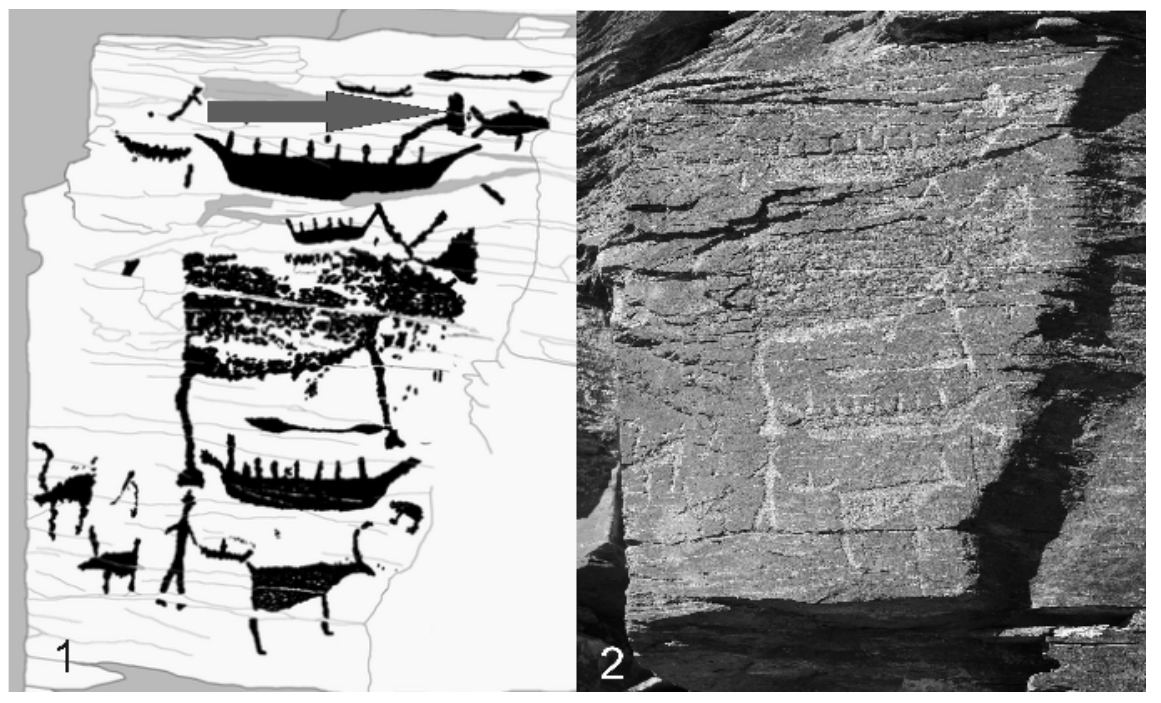

Foto VII: Ekaterina Devlet, agm., s. 121. Fig: 8.2

16 Ekaterina Devlet, "Rock Art Studıes In Northern Russıa And The Far East, 2000-2004", Rock Art Studies News World III, Ed. Paul Bahn - Natalie Franklin - Matthias Strecker 2008, s. 121, Fig:8.2

17 Mihaly Hoppal, Şamanlar ve Semboller; Kaya Resmi ve Göstergebilim, çev. Fatih Sel, İstanbul 2015, s. 79, resim: 11.5.4; 11.5.5. 

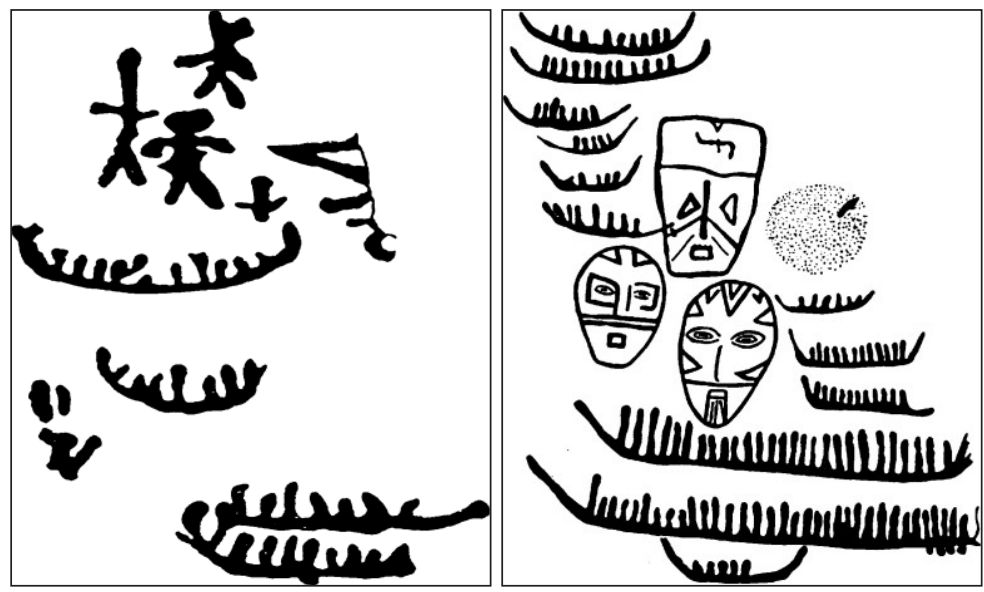

Çizim X-XI: Hoppal, age., resim: 11.5.4; 11.5 .5
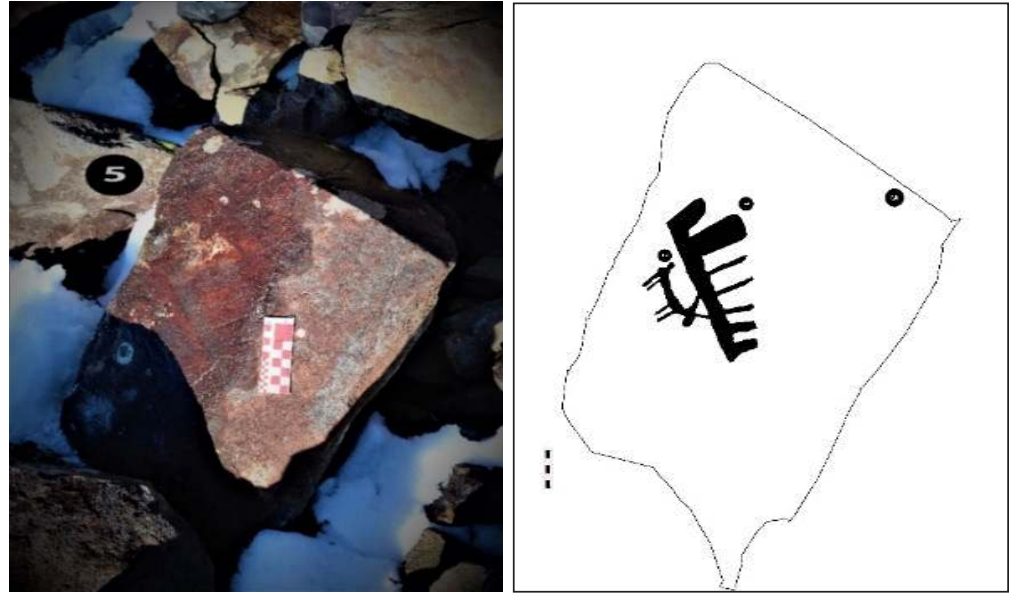

Foto VIII: V No.lu Kaya

Çizim XII: V No.lu Kayanın Çizimi

VI No.lu Kaya: Kayalık alanın en alt kısmında, yani yola bakan tarafta, yarıdan fazla kısmı toprağa gömülmüş ve üst tarafi konturlu bir taş üzerinde $10 \times 15 \mathrm{~cm}$ ebatlarında ortadaki merkezden radyal ışınlarla tasvir edilmiş bir güneş kursu yer almaktadır. Bölgeye çok yakın olan Şenkaya Kaynak Köyü ${ }^{18}$ kaya panolarında,

18 Özgül, "Erzurum Şenkaya...", s. 379. 
Kars Doyumlu'da ${ }^{19}$, Erzincan Kemaliye Dilli Vadisi'ndeki ${ }^{20}$ kaya resimlerinde güneş kursuna rastlanmıştır. Ancak belirtilen kaya resim alanlarındaki güneş kursu bağımsız bir şekilde resmedilmişken, buradaki güneş kursu 5 çizgi arasında tam ortaya konumlandırılmış çizgisel bir platform üzerinde resmedilmiştir. Bu çizgilerin oturtulduğu nesne, bir ocak da olabilir, ateş kültü ile alakalı başka bir şey de olabilir. Nitekim kaya resim alanında yer alan ve daha belirgin bir biçimde yapılmış başka bir güneş kursunun varlığı, buradaki kozmik inanışlarla ilgili bir düşünceyi yansıtmış gibidir (Foto IX-Çizim XIII).

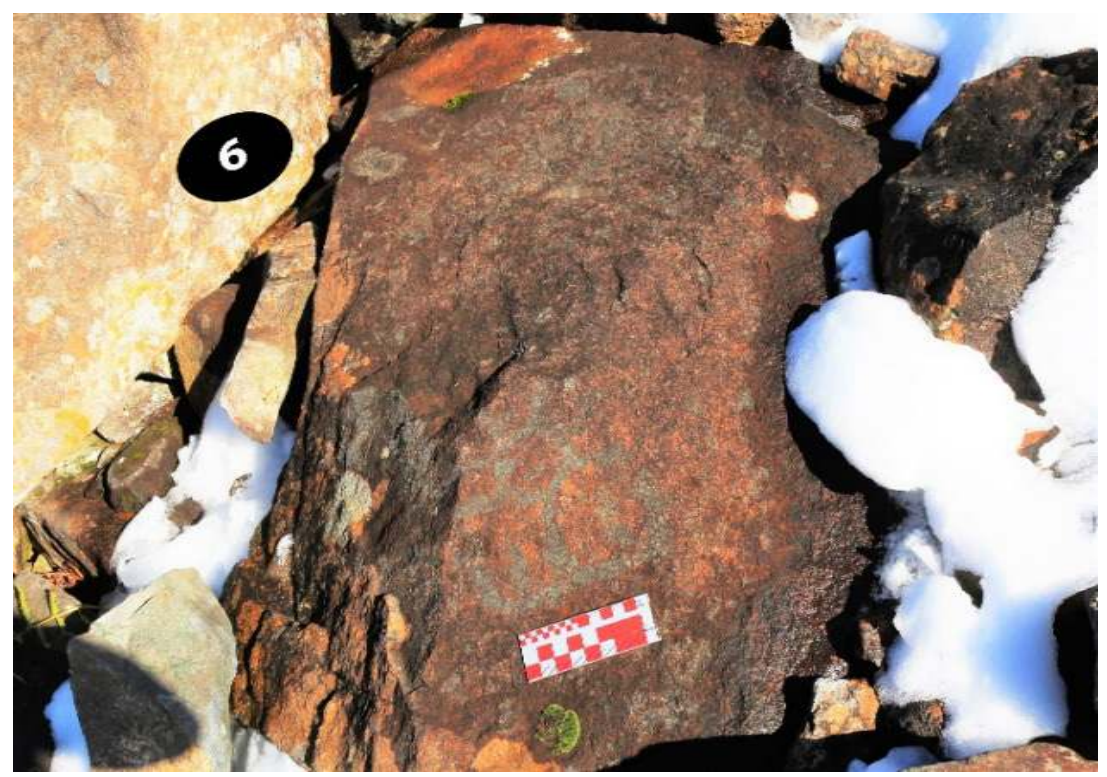

Foto IX: VI. No.lu Kaya

19 Günaşdı, agm., s. 395.

20 Ceylan, "Türk Dünyasından...”, s. 167.; İbrahim Üngör, "Türk Kültüründe Dă̆ Keçisi/Teke Ve Doğu Anadolu Petrogliflerinde Bulunan Dağ Keçisi/Teke Figürleri Üzerine Görüşler” IV. Uluslararası Türk Şöleni Türk Kültürü Sempozyumu Bildirileri, Erzurum 2018, s. 326. 


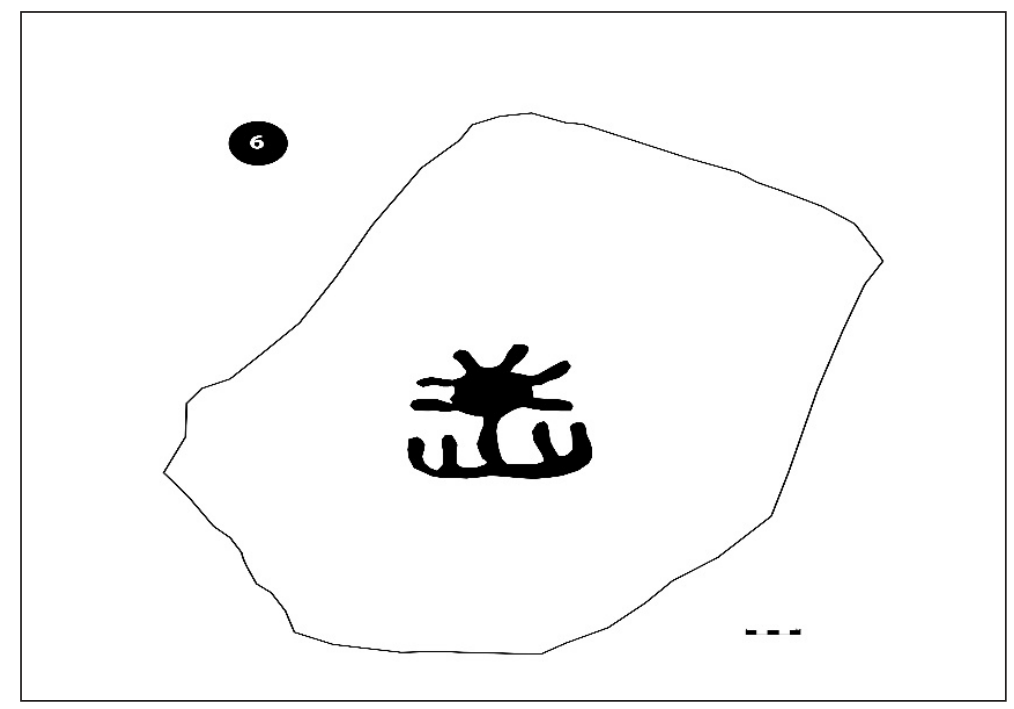

Çizim XIII: VI. No.lu Kayanın Çizimi

VII No.lu Kaya: 6 no.lu kayanın 5 m kuzey tarafinda üzeri karla kaplı olan yassı bir taşın doğu tarafinda koşar vaziyette bir at tasviri yer almaktadır. Atın yüz kısmı gövdeye kıyasla orantısız bir biçimdedir. Kuyruğu düğümlenmiş gibidir. Arka ayakları oldukça düz ve çizgisel bir profil vermektedir. Avrasya kaya resim sanatında bu şekilde yapılmış at tasvirlerinin Erken Tunç Çăğ’ndan itibaren ortaya çıktığı görülür ${ }^{21}$. Avrasya kıtası ve özellikle Güney Sibirya-Moğolistan kaya resimlerindeki çeşitli hayvanların resimlerinin evrimini inceleyen Macar bilim adamı M. Hoppal, güneş, geyik, at, boğa, dă̆ keçisi, doğum, savaşçı, koyun, yılan, simgelerinin kronolojisi ile ilgili verdiği tablo, bu tür resimlere pek çok açıdan ışık $\operatorname{tutar}^{22}$ ( Çizim XIV). Bizim burada tespit ettiğimiz at figürü ise, üslup bakımından en çok Ardahan Başköy kaya resimlerindeki at tasvirlerine benzer ${ }^{23}$ (Çizim XV). Başköy'deki at figürlerinin kuyrukları daha uzun, gövde kısımları düz çizilmişken, buradaki figürde atın sırt ve gövde kısmı daha yayvan ve basık bir biçimde çizilmiştir. İki ayrı resimde de ortak olan öge, yapım tekniklerinin aynı (kazıma-vurgu) ve ikisinin de hareket halinde olmalarıdır (Foto X-Çizim XVI).

21 Rogozhinskiy, agm., s. 9; E. Jacobson-Tepfer, The Life of Two Valleys in the Bronze Age. Rock Art in the Mongolian Altai, Luminaire Press, 2019, s. 82.

22 Hoppal, age., s. 18, Figür. I.1.16.

23 Ceylan, "Ģıldır Başköy...”, s. 27. 


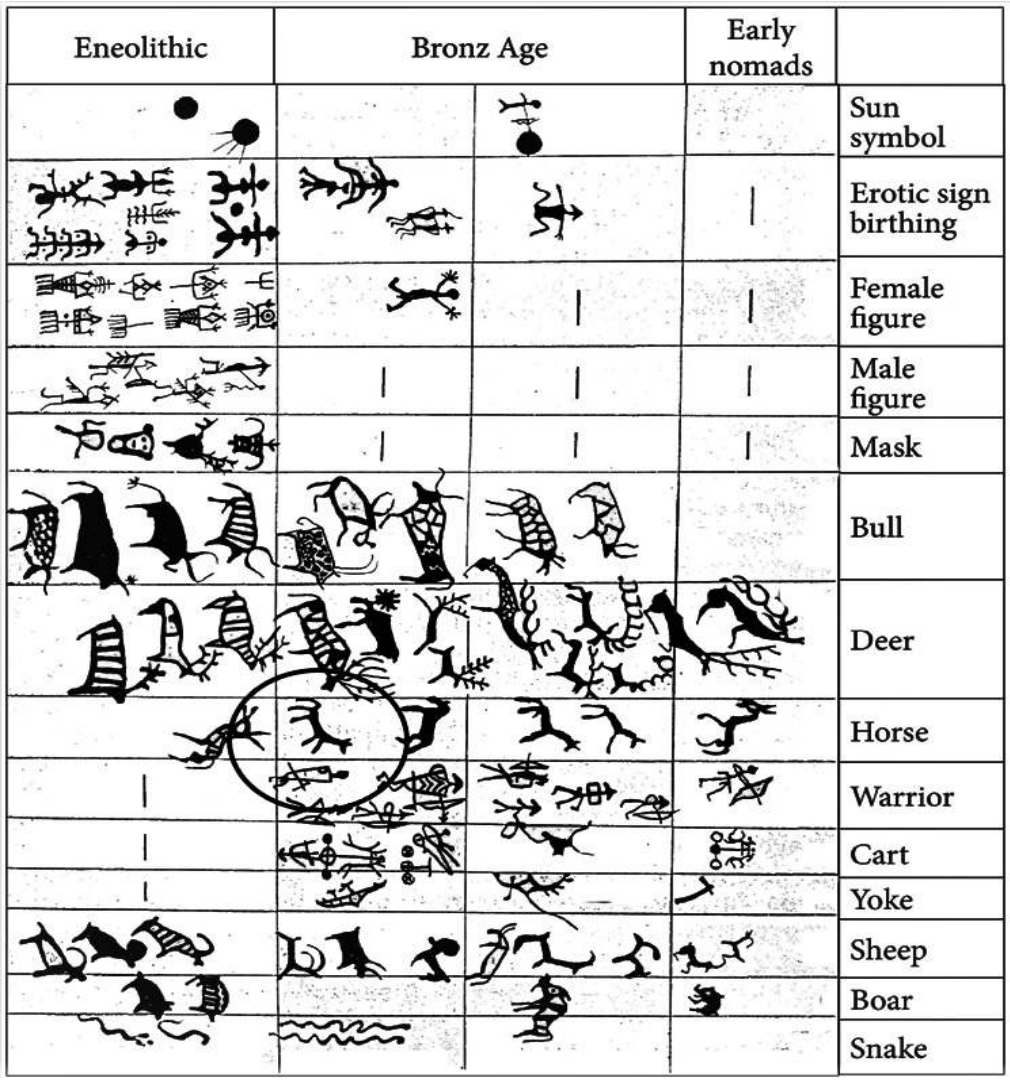

Çizim XIV: Figürlerin Tarihlendirilmesi (Hoppal, age., Figür. I.1.16.)

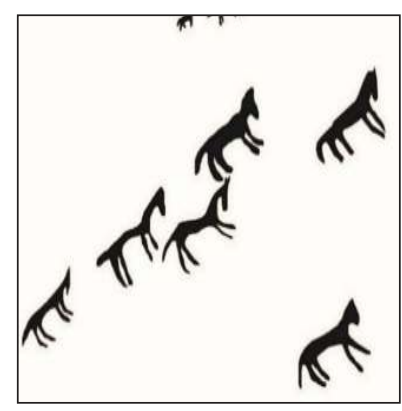

Çizim XV: Çıldır At Çizimleri Ceylan, "Çıldır Başköy..." s. 27

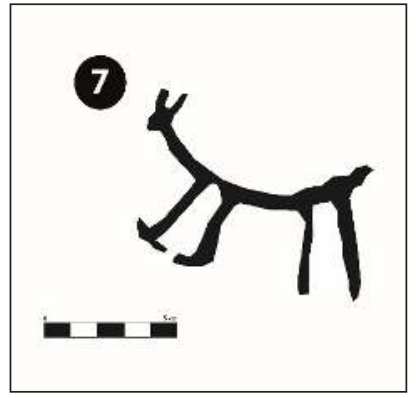

Çizim XVI: VII No.lu Kayanın Çizimi 


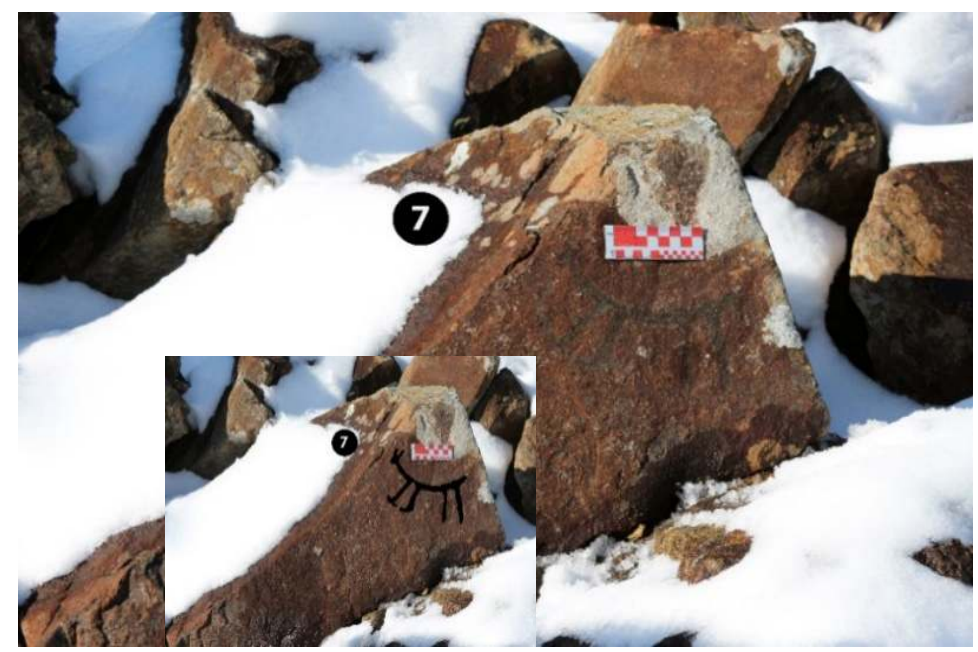

Foto X: VII. No.lu Kaya

VIII No.lu Kaya: Tanımlanamayan bir hayvan. Arka iki bacağı simetrik bir biçimde ve orantılı şekilde yapılmış, kuyruğu içe doğru kıvrılmış, üst kısmı da sanki bir yırtıcı kuşun gövdesini andırmaktadır. Bununla birlikte tam olarak anlamlandırılamayan bir hayvan figürüdür (Foto XI-Çizim XVII).

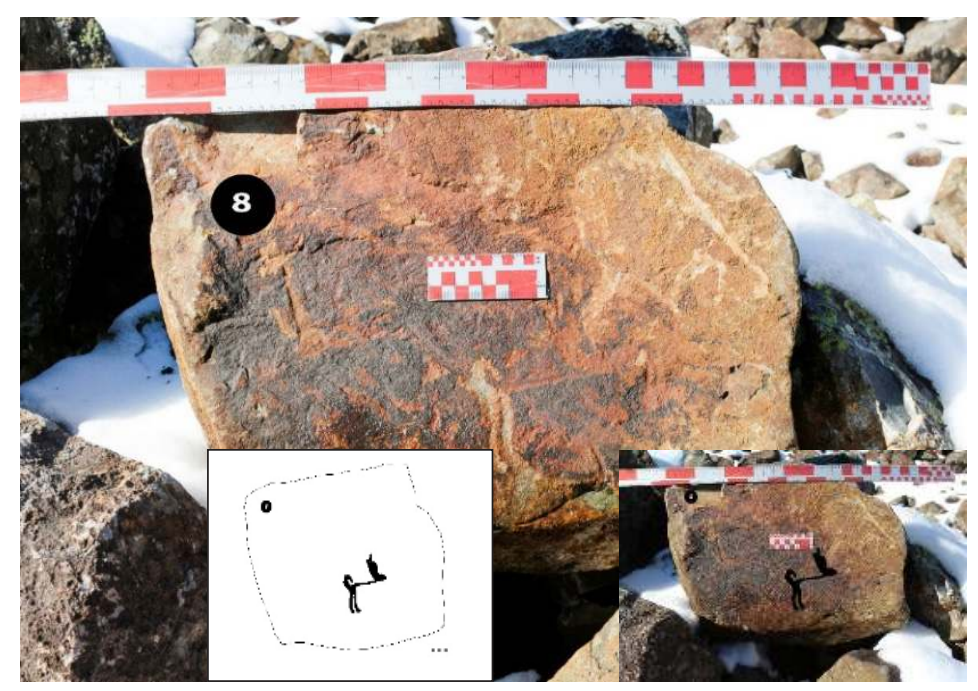

Foto XI-Çizim XVII: VIII. No.lu Kaya 
IX No.lu Kaya: 1 no.lu büyük kayanın 7 m aşağısında üçgenimsi görünümü andıran bir kaya parçası üzerinde 4 adet figürün yer aldığı bir av sahnesi betimlenmiştir. Kayanın alt tarafinda 4 numara ile belirtilen bir avcı, okunu 3 numara ile belirtilen tekeye doğru firlatırken çizilmiştir. Avcı çizgisel bir formda ve yaya olarak betimlenmiştir. 3 numara ile belirtilen ve teke olduğu anlaşılan hayvanın boynuzları oldukça uzun ve gövde ile orantısız bir biçimde, ön ayakları arkadakilerden daha kısa betimlenmiştir. Onun hemen arkasında 2 numara ile belirtilen figürde ise abartılı boynuzlu bir geyiğin avcı tarafından avlanmış hali resmedilmiştir. 1 numarada ise oldukça büyük bir örümcek tasviri yer alır (Foto XII-Çizim XVIII-XIX).

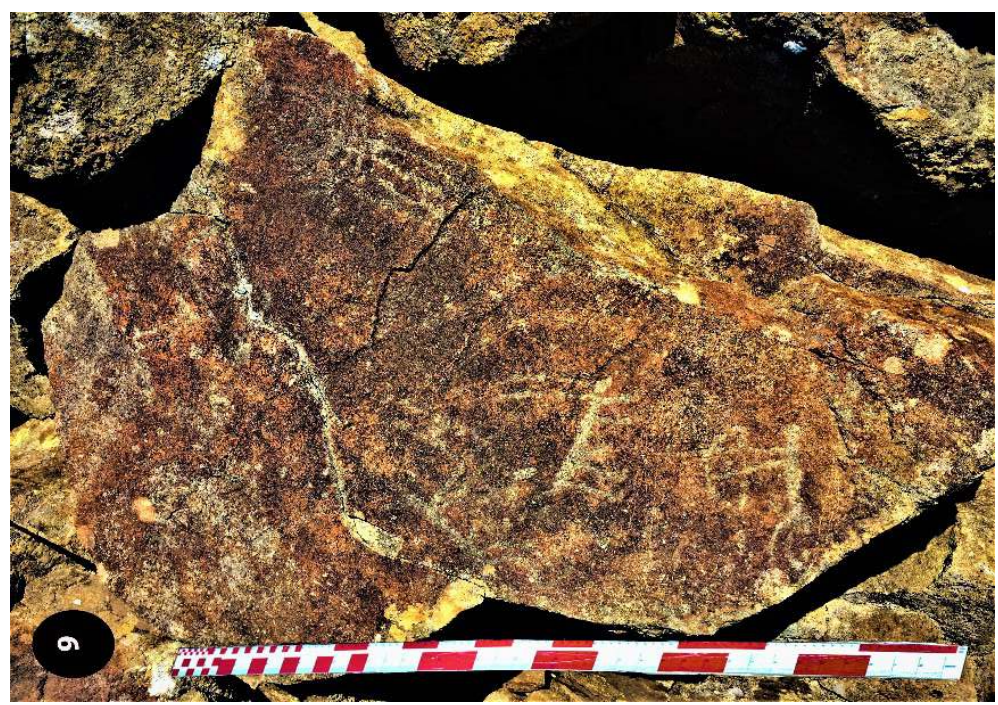

Foto XII: IX. No.lu Kaya 


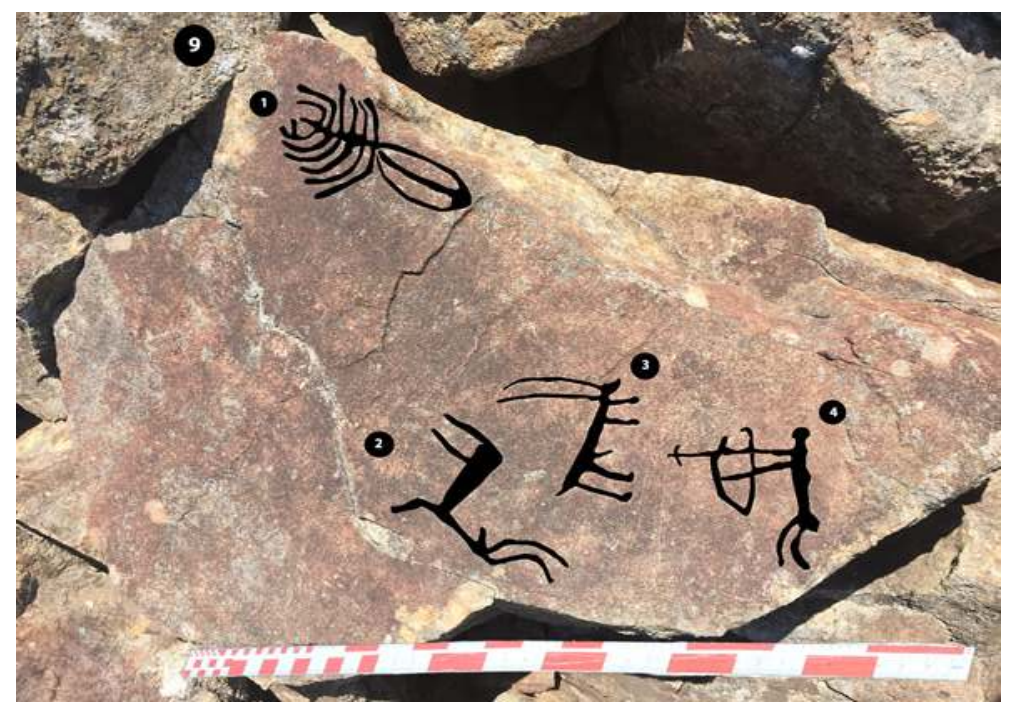

Çizim XVIII: IX No.lu Kayanın Çizimi

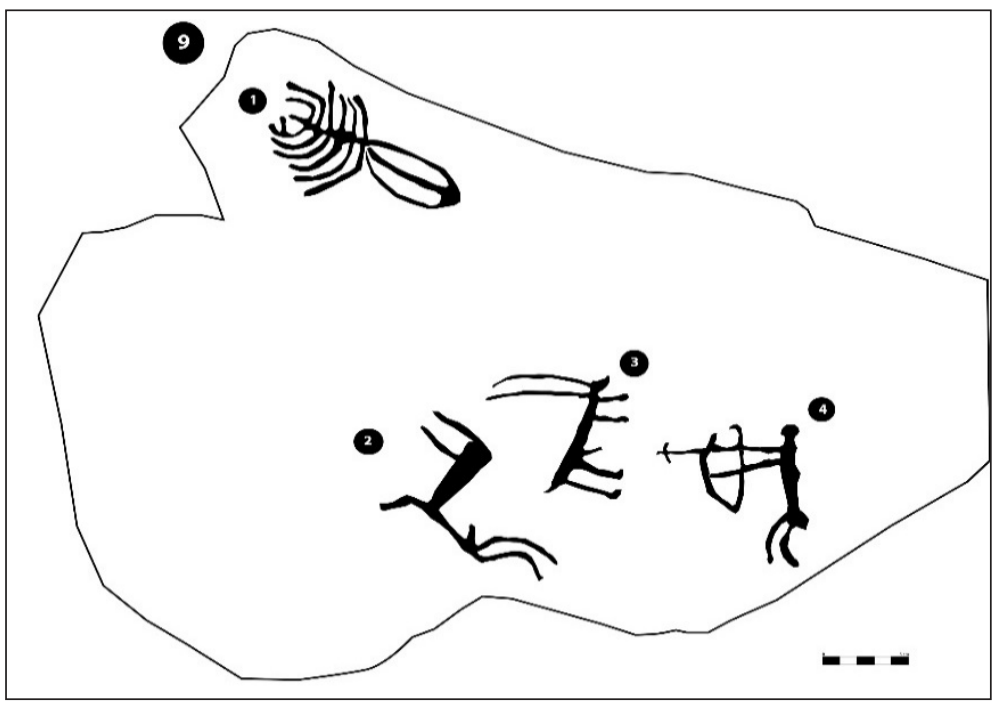

Çizim XIX: IX No.lu Kayanın Çizimi

Benzer av sahnesine Kars Dolaylı kaya resim alanında rastlanır. Bu iki ayrı kaya resim alanındaki av sahnesinin benzer özellikleri arasında av hayvanlarının dört 
ayaklı olması ve cepheden çizilmelerini sayabiliriz. Yine Dolaylı'daki keçi figürünün boynuzları oldukça uzun ve iri çizilmiştir (Foto XIII-Çizim XX). Bununla birlikte buradaki keçinin boynuzları ise daha orantısal ve dik çizilmiştir. Farklı olarak Dolaylı'daki resimde daha çok çizgi tekniği kullanılmış iken, burada ise vurma tekniği kullanılmıştır. O yüzden hatlar biraz daha belirsiz, ama ustacadır.

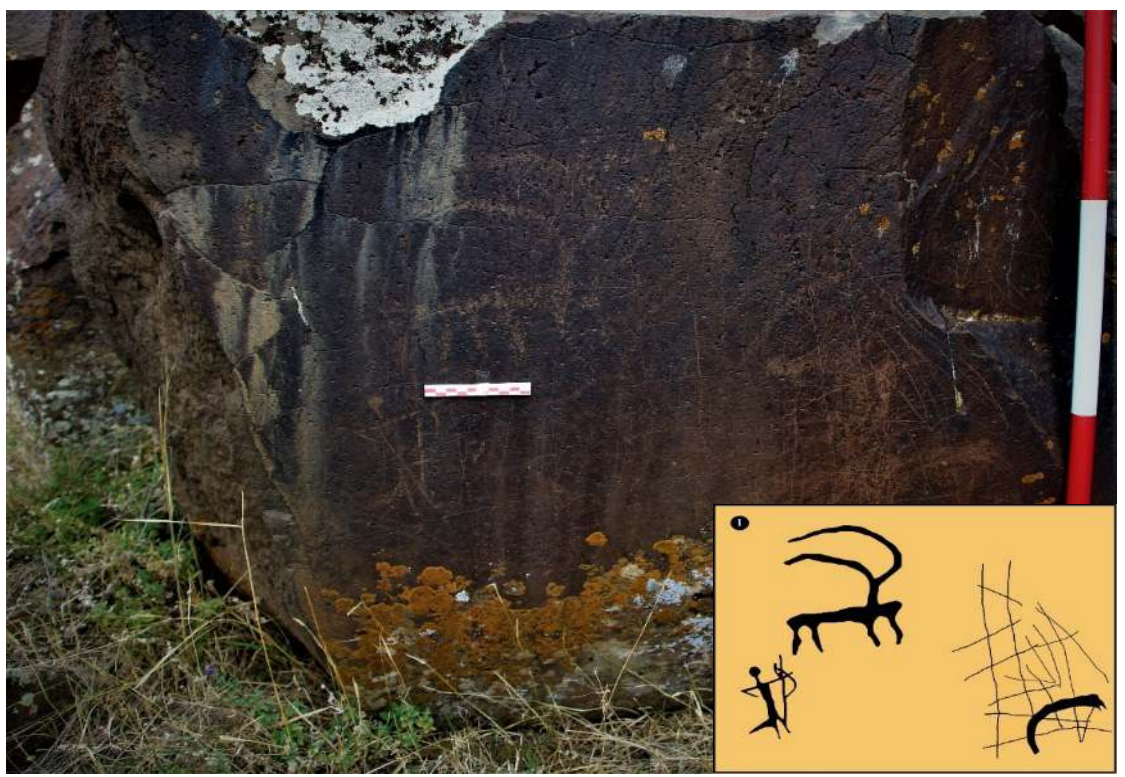

Foto XIII-Çizim XX: Ceylan 2018, Figür: 5

X No.lu Kaya: 2014 yılında O. Hacıoğlu tarafindan kamuoyuna duyurulan 10 no.lu kayayı, taşların yerleri sürekli olarak yer değiştirmesinden dolayı 2019 yılı yüzey araştırmamızda bulamadık. Bununla birlikte bizimle çalışmaya katılan C. Velimahmutoğlu, bize burada bu kayanın olduğunu ifade ederek kayanın resmini kendisinin çektiğini söyledi. X no.lu kaya üzerindeki çalışmamızı ise, Velimahmutoğlu'nun vermiş olduğu resimler üzerinden yürüttük.

$\mathrm{X}$ numaralı kaya üzerinde üç adet figür yer almaktadır. Figürlerde diğer resimlerden farklı olarak gagalama (pecked) tekniğinin uygulandığı görülür. Sivri ve kesici bir aletle (muhtemelen tunç/tunç karışımı) milimetrik dokunuşlar ile kaya yüzeyine uygulanan bir resim tekniğidir. Örneklerine dünyanın pek çok yerinde rastlanmakla birlikte Avrasya kaya resim sanatında fazlaca görülür. Tamgalısay'da MÖ II. binden başlayıp MÖ XIV-XIII. yüzyıla kadar devam eden kaya resimlerinde, 
Saymalıtaş’ta, Sarmışsay kaya resimlerinde bu yöntemle ilgili güzel örnekler yer alır ${ }^{24}$.

Kaya üzerindeki 1 numara ile belirtilen resim bir süvariyi tasvir etmektedir. Atın üstündeki insan, çizgisel karakterdedir ve fazla belirgin değildir. Atın baş kısmı öne doğru, kuyruk kısmı ise sırt ile aynı derecede biraz aşağı doğru eğimli çizilmiştir. Atın kulaklarının biri tahrip olduğu için tek kulaklı gibi gözükmektedir. Atın ön ve arka ayakları orantısal bir biçimdedir. Yalnız atın arka ayaklarının hemen ön kısmında bir ayak gibi çizilmiş uzantı yer almaktadır. Bu uzantı, muhtemelen atlını kırbacını ya da çubuğunu simgelemektedir. Çünkü aynı görüntü 2 numaralı süvaride de görülmektedir. Böylesine dikkatli hatları çizmesini bilen bir ressamın, atları beş ayaklı tasvir etmesi pek mantıklı değil. 2 numaralı figürde ise 1 numara ile aynı orantıya sahip başka bir süvari resmedilmiştir. Ancak bu atın üstündeki süvari ellerini yukarı doğru kaldırmış, atı ile birlikte oldukça coşkulu bir şekilde ileriye doğru koşar bir durumda çizilmiş̧ir. Bu atın kulakları tam olarak belli olmaktadır. Yandan profil şeklinde çizildiği için atın diğer kulağı biraz daha kısa gözükmektedir. Kuyruk kısmı, bel kısmı ile aynı seviyede ve diğer atta olduğu gibi kısa çizilmiştir. 3 numarada ise bu iki süvarinin arka kısmında içinde 9 çıkrığı olan güneş sembolü yer almaktadır. Güneş sembolü oldukça orantılı düzgün bir biçimde çizilmiştir. Güneş sembolünün içindeki astral çizgiler ortada birleşmektedir. Dörtnala güneşe uçan atlıların olduğu bu sahne, kozmik bir inanışın önemli bir parçası gibi durmaktadır (Foto XIV-XV-Çizim XXI-XXII).

24 Rogozhinskiy, agm. s. 17.; Vadim Ranov, "Petroglyphs of Tadjikistan", Petroglyphs of Cenrtal Asia, Ed. K. Tashbayeva, 2001, s. 126; Muhiddin Khujanazarov, "Rock Art Sites in Uzbekistan”, Rock Art in Central Asia, Ed. J. Clottes, Paris 2011, s. 111. 


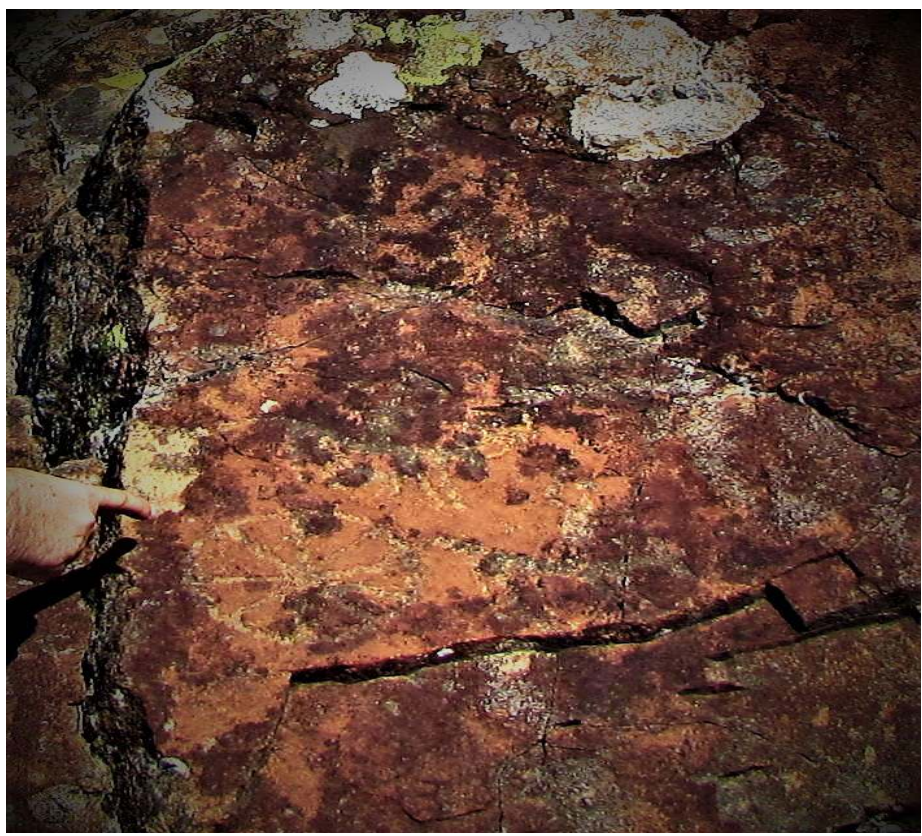

Foto XIV: X No.lu Kaya

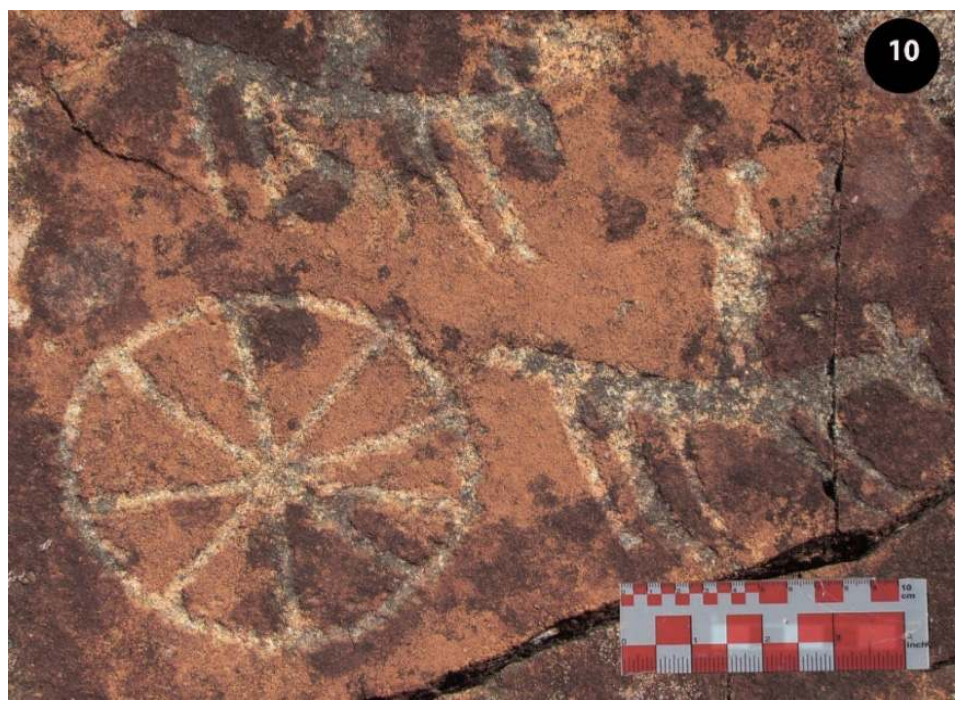

Foto XV: X. No.lu Kaya

Belleten, Aralık 2021, Cilt: 85/Sayı: 304; 781-818 

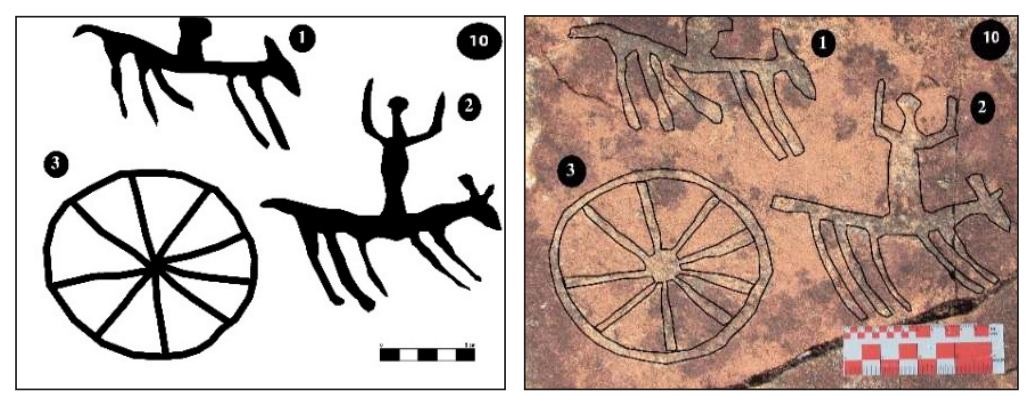

Çizim XXI-XXII: X No.lu Kayanın Çizimi

XI No.lu Kaya: XI no.lu kaya üzerinde 5 numaralı kayadakine benzer bir biçimde yapılmış bir sandal/kayık ve onun hemen üzerinde baş kısmı tahrip olduğu için, tam olarak anlamlandırılamayan dört bacaklı bir hayvan resmedilmiştir. Diğerinden farklı olarak burada yapılan sandal daha simetrik ve ölçülüdür. Içerisinde taşımış olduğu 11 insan sembolü ile sandal çok vurgulu bir biçimde ve oyma tekniği ile yapılmıştır (Foto XVI-XVII-Çizim XXIII).

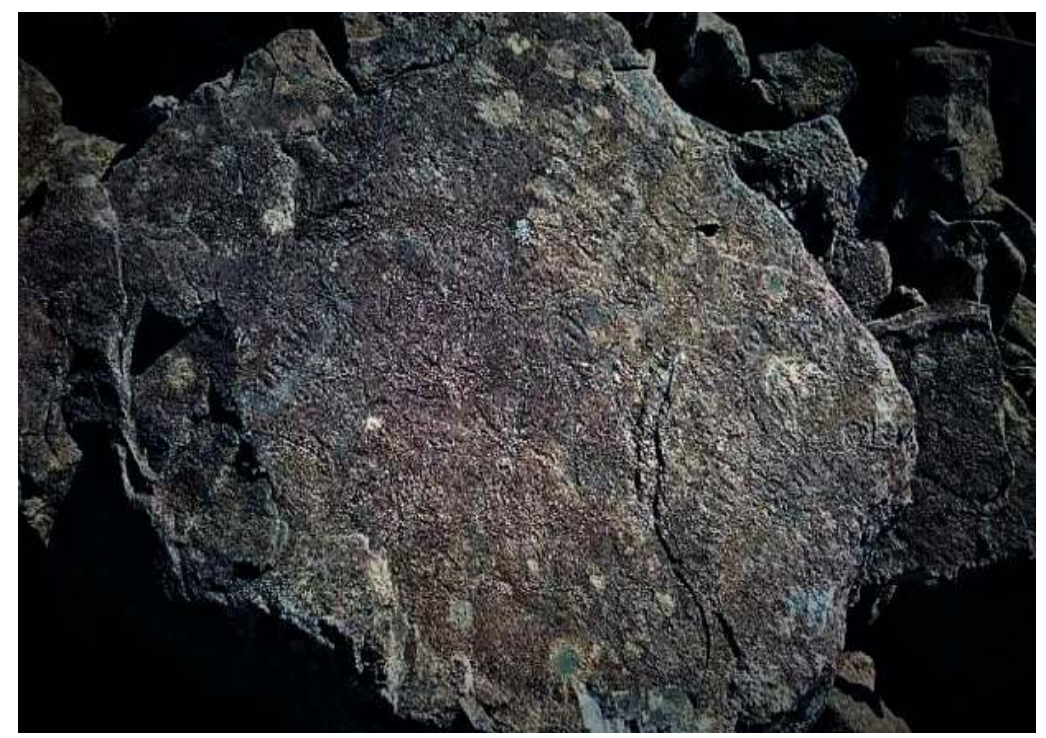

Foto XVI: XI No.lu Kaya 


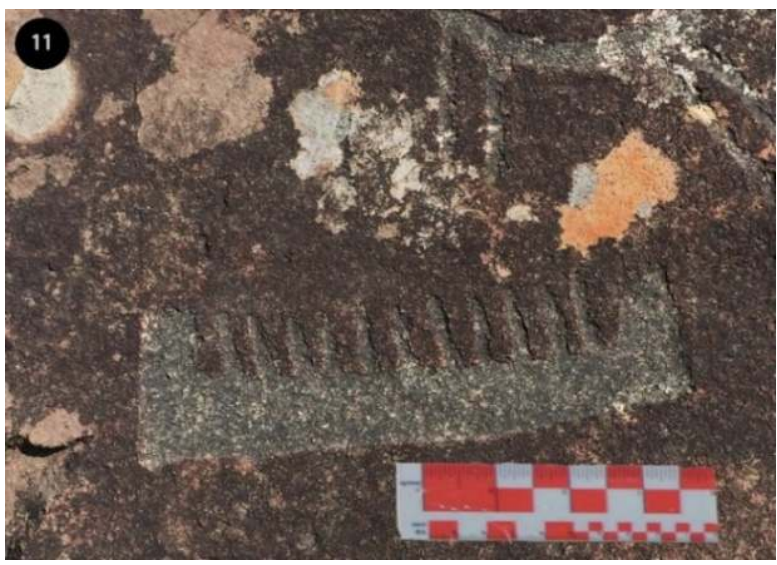

XVII: XI No.lu Kaya

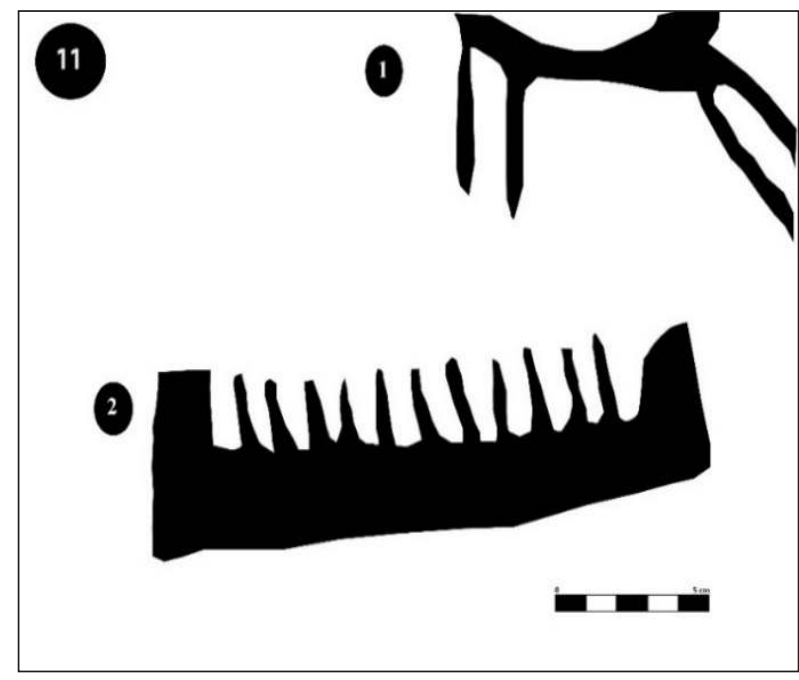

Ģizim XXIII: XI No.lu Kayanın Çizimi 


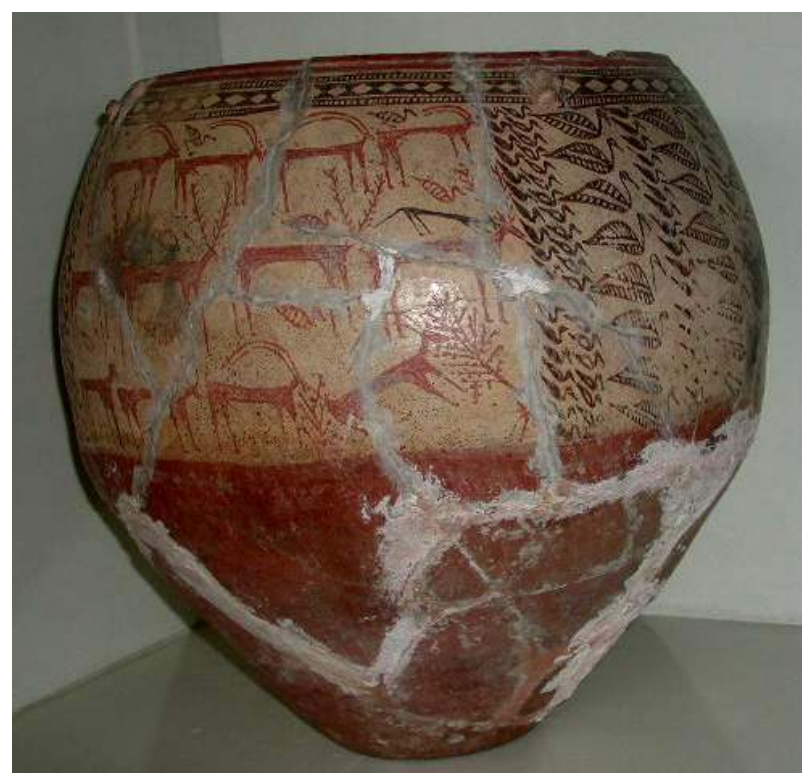

Foto XVIII: Dă̆ Keçisi Bezemeli Tunç Dönemi Çömlek (Erzurum Arkeoloji Müzesi-A. Ceylan Arşivi)

\section{Tartışma ve Sonuç}

Doğu Anadolu'da bugüne kadar tespit edilmiş kaya resim alanları incelendiğinde, kaya resimlerinin göçer toplulukların yaşamış olduğu coğrafyalarda ortaya çıtığı görülür. Yaygın bir etkiye sahip Orta Asya kaya resim sanatı, yerleşik kültürden ziyade göçer kültürlerin etkili olduğu bozkır kuşaklarında yayılma imkânı bulmuştur. Anadolu bozkır kuşağı, Doğu Anadolu'nun yüksek yaylaları, Kafkasya, Kuzeybatı İran, Türkmenistan, Özbekistan'ın dağlık alanlarında ortaya çıkan kaya resimlerinin Altay-Sibirya kaya sanatı ile benzer özellikler taşıdığı yapılan çalışmalarla ortaya konulmuştur.

Kaya resim alanlarının Anadolu'daki dağılımında yoğunluklu olarak üç bölge göze çarpar. Bunlar; Doğu Karadeniz Bölgesi, Doğu Anadolu'nun Erzurum-Kars-Ardahan Platosu ve Hakkâri-Van Bölgesi'dir. Bu bölgeler aynı zamanda bozkır halklarının tarih boyunca Anadolu'ya ve Ön Asya'ya gelmek için kullandıkları güzergâhları oluşturmuşlardır. Bugün bu güzergâhların tarihi ve arkeolojik özellikleri yeteri derecede aydınlatılmış olmasına rağmen, hala eksik olan pek çok nokta vardır. 
Kaya resim sanatı bakımından Doğu Karadeniz Bölgesi’ndeki ilk örnekleri barındıran Demirkapı/Arılı kaya resimleri, birbirinden güzel örnekler sunan çeşitli temalar ve bağımsız resimler ile çok özel bir alanı temsil etmektedir. Kaya resim alanı, çalışmamızın başlangıç kısmında da ifade ettiğimiz gibi bir ritüel alanı özelliği gösteren semboller içerdiği gibi; pastoral hayatın günlük akışını tasvir eden resimlerin yer aldığı bir çeşit göçer bir yurt/oba yaşantısını yansıtan temaları da içerir. Bölgenin hem deniz kültürüne hem de yüksek rakımından dolayı yayla kültürüne sahip olması, her iki kültür ögelerinin resimlerde yer almasını sağlamıştır. Hayvancılık ile balıkçılı̆̆ı bir arada yürüten bu insanların, kayıkları/sandalları ritüellerinin bir parçası olarak görmeleri, kaya resim alanını daha da mistik bir hale getirir. Deniz kültürünü yansıtan sandal, balık ve avlanmış balık sahneleri, daha önce yakın çevre ve diğer bölgelerde hiç rastlanmayan tasvirler olarak karşımıza çıkar. Özellikle sandalların/kayıkların insanları veya ölen diğger canlıları başka dünyalara ruhlarını taşıması gibi, kökleri Sibirya Şamanizmi’ne dayanan inanışların tasvir edilmesi bizleri şaşırtmıştır. Bununla birlikte dağ keçisi ve tanımlanamayan başka bir hayvan üzerinde ellerini açmış dünyalar arası yolculuk yapan insanların/şamanların tasviri de çok ilginçtir. Yine farklı olarak I numaralı panoda ilkel bir formda çizilmiş çadır resmi de oba yaşantısının önemli bir parçassını açıkça gösteren öge olarak karşımıza çıkar. Buna ilaveten XII No.lu kayadaki av sahnesi, avcı-toplayıcı yaşamın temel bir özelliğini yansıtır. Bu tür sahnelerin benzer örneklerine yakın bölgedeki Kars Digor/Dolaylı kaya resimlerinde rastlanır.

Kaya resimlerinde kullanılan teknik, çoğunlukla Doğu Anadolu kaya resimlerinde sıkça kullanılan vurma-oyma-çizgi teknikleridir. Burada farklı olarak, gagalama (pecked) yönteminin X numaralı kayada uygulandığı görülür. Demirkapı/Arılı kaya resimlerinin analojik bakımdan özellikle Doğu Anadolu'nun Erzurum-Kars Platosu ile Hakkâri bölgesi kaya resimleri ile örtüştüğü anlaşılmaktadır. Stilistik ve grafiksel bakımdan ortaya çıkan benzerliklerin yanı sıra, bu bölgelerin yüksek rakımlı bir yayla olma özelliği taşımaları ve küçükbaş hayvancılık için uygun yerler olması, bu benzerliklerde öne çıkan unsurlardır. Konu ile ilgili ilginç olan başka bir unsur da; Erzurum-Hakkâri dağlık bölgesinin benzer kaya resim örneklerinin yanı sıra; benzer taş heykellerini de barındırmalarıdır. Bu özellikler, iki bölgenin Tunç Çă̆ı'ndaki kültür birliğine işaret eder.

Kaya resimlerinin tarihlendirilmesi konusunda maalesef elimizde yeterli derecede kanıt yoktur. Kaya resim alanının hemen yakınlarında bir kurgan, yerleşim yeri (kale, nekropol, kaya mezarı vb.), ya da seramik bulgusuna rastlanılmadığı için 
kesin olarak hangi tarihte yapılmış olabileceklerine dair net bilgilerimiz şimdilik yoktur. Buna rağmen, kaya resimlerindeki hayvan tasvirlerinin biçimsel özellikleri, yapım tekniklerinin analoji yolu ile çevre coğrafyalarla mukayesesi, bize bu konuda belli ölçülerde fikirler vermiştir. Buradan yola çıkarak Demirkapı/Arılıkaya resimlerinin Erken Tunç Çağ'ı ve Orta Tunç Çağı'nda yapıldıklarını söyleyebiliriz. Özellikle XIV-XVII numaralı resimlerde gagalama (pecked) tekniğinin kullanılmış olması, bu resimlerin Orta Tunç Çağı'nda yapıldıklarını düşündürür. Bununla birlikte şaman ritüellerinin yer alması da bu resimlerin Erken Tunç Çağı’nda yapıldığı fikrini akla getirir. Çünkü bu tür ritüel tasvirlerin, genellikle Avrasya kuşağında Tunç Çaăıı'nda ortaya çıkmaya başladığı görülür. Bununla birlikte bazı sahnelerdeki dağ keçisi formunun da yakın bölgelerde de (Borluk Vadisi) görüldüğü gibi, Erken Tunç Çağı'ndan itibaren ortaya çıktığı görülmektedir. Doğu Anadolu'nun bazı kazı merkezlerinde Erken Tunç Çağı'ndan itibaren ortaya çıkan çanak-çömlek üzerinde dağ keçisi tasvirlerinin bulunması da bölgedeki kaya resimlerinin tarihlendirilmesi konusunda önemli bir mukayese imkânı sunmakta$\operatorname{dir}^{25}$ (Foto XVIII).

Kaya resim alanının işlevinin ne olduğu ya da bölgede pek çok yer olmasına rağmen Tunç Çağı insanlarının neden bu bölgeyi seçtiği konusuna bir açıklama getirmek gerekmektedir. Bu konudaki görüşlerimizi şu şekilde detaylandırabiliriz. Birincisi, buranın bir ritüel alanı olduğu yönündedir. Bu tezimizi III-IV-VIII-XIV numaralı resimlerin desteklediğini iddia edebiliriz. Bu resimlerde Şamanizm öğelerini içeren tasvirler yer alır. Orta Tunç Ģağı'ndan itibaren bozkır kavimleri arasında yayginlaşan ve bir inanç kültürü olarak karşımıza çıkan bu tür tören sahneleri, Saymalıtaş-Tamgalısay vb. açık hava tapınaklarında çok açık bir şekilde karşımıza çıkar. Benzer ritüel sahneleri Kars/Digor Dolaylı kaya resimlerinde de göze çarpar.

İkinci bir görüş olarak kaya resim alanı, konar-göçer yaşam süren toplulukların yaylağı gibi düşünülebilir. Bilindiği gibi bozkır toplulukları tarih boyunca yazın yüksek yerlere, kışın ise daha alçak yerlere göçüyorlardı. Burada buna benzer bir hayatın varlığını petrogliflerdeki birbirinden bağımsız resimlerden anlayabiliriz. Kaya resimlerindeki av sahneleri, çadır, ateş, ocak, vahşi hayvan vb. tasvirler, yaylak hayatından sahneler olarak karşımıza çıkar. Bütün kayalık alan tarandığı zaman daha başka resimlerin de olduğunu düşünüyoruz. Yeni bulunacak kaya

25 Oktay Özgül-Burak Bingöl "Kuzeydoğu Anadolu Petrogliflerindeki Bir Grup Dağ Keçisi Motifi”, Art-Sanat, İstanbul, 16/2021, s. 517-518-519. 
resimlerinde yaylak hayatı hakkında daha detaylı bilgi veren eğlence, oyun, savaş vb. hareketli kompozisyonları da bulabilmemiz mümkündür. Kaya resimleri, bize bölgedeki hayvan faunası hakkında da bilgiler verir. Resimlerde yer alan ve tarafimızdan bizon olarak yorumlanan bir figürün muhtemelen Kafkas bizonu olduğunu ve neslinin tükenmiş olduğunu ifade edebiliriz. Yine XII no.lu panodaki abartılı çizilmiş bir örümceğin varlığı dikkat çekicidir. Bu resimler, bölgenin geçmişteki hayvan popülasyonunun araştırılmasının da önünü açar.

Kaya resimlerinin yer aldığı kayalık alan açısından en büyük risk; bu sahada sürdüğü anlaşılan erozyon nedeni ile kayaların parçalanması, korozyona uğraması ve benzeri nedenler sonucu yok olma ihtimalidir. Bunun önüne geçmek için yerinde koruma dediğimiz bir yöntemle kayalara işaret verilerek koruma altına alınmaları önerilebilir. Bu konu ile ilgili yapılacak çalışmalar hakkındaki önerilerimizi Kültür ve Turizm Bakanlığı'na 2019 yılında sunduk.

Sonuç olarak şunu söyleyebiliriz: Demirkapı/Arılı kaya resimleri, bölgenin Eskiçağına yönelik belki de en eski kanıt olma özelliği taşımaktadır. Sonraki yıllarda bölgede yapacağımız detaylı çalışmalarla Arılı kaya resimleri hakkında çok daha fazla bilgimiz olacaktır. Petrogliflerle ilgili sır perdesini ortadan kaldıracak bulguların, bu insanların mezarlarından geleceğini düşünüyoruz. Gelecekteki araştırmaların mezarlar üzerine yoğunlaşması gerektiği kanaatindeyiz. 


\section{KAYNAKLAR}

Augustinová, Anna - Stančo, Ladislav, "The Petroglyphs of Pashkhurt Valley in the Surkhan Darya Province (South Uzbekistan) - Preliminary Report", Studaa Hercyma XX/2, 2016, s. 122-138.

Baxşeliyev, Veli, Gamikaya Tasvirleri, Bakü 2003.

Belli, Oktay, "New light on the Earliest Art of Anatolia: Kızların Mağarası (The Cave of the Maidens)", Turkish Treasures 2, İstanbul 1978, s. 28-31.

Belli, Oktay, Her Yönü İle Ani, İstanbul 2019.

Bingöl, Akın, "Yüzey Araştırmaları Işı̆̆ında Borluk Vadisi Kayaüstü Resimleri", Selçuk Üniversitesi Türkiyat Araştrmalan Dergisi, S. 39, Konya 2016, s. 347-355.

Bingöl, Burak, Kuzeydoğu Anadolu Petroğliflerindeki Dağ Keçisi Motifi, (Yayımlanmamış Yüksek Lisans Tezi), Atatürk Üniversitesi Türkiyat Araştırmaları Enstitüsü, Erzurum 2020.

Caferqulu, Namazoğlu - Muradova, Firuze - Memmedrza q1z, Gobustan Petroglifleri, Bakü 2003.

Ceylan, Alpaslan, Sarkamıs, Tarihi ve Arkeolojik Araştırmalar, Ankara 2001.

Ceylan, Alpaslan, "Erzurum Ovası'nda Önemli Bir Merkez: Cinis Höyük", Atatürk Üniversitesi Fen-Edebiyat Fakültesi Edebiyat Bilimleri Arasțtrma Dergisi-26, Erzurum 2001, s. 29-41.

Ceylan, Alpaslan, “Doğu Anadolu'da Illk Türk Yerleşmelerinden Cunni Mağaras1", Türkler Ansiklopedisi, G 6, Ankara 2002, s. 425-429.

Ceylan, Alpaslan, "Erzurum ve Çevresinde Erken Dönem Türk İzleri”, Türk Kültürü, Erzurum 2004.

Ceylan, Alpaslan, "Çıldır Başköy Kaya Resimleri”, Belgü, 2(2), 2015, s. 7-24.

Ceylan, Alpaslan - Akın Bingöl - Mustafa Karakeçi, Eski Çağda Kars Kaleleri, Erzurum 2018.

Ceylan, Alpaslan, "Türk Dünyasından Yeni Kaya Resimleri”, Türk Tarih Kongresi (17/1), 2018, s. 155-206.

Ceylan, Alpaslan, 2018, "Doğu Anadolu'da Erken Dönem Türk İzleri III Kars-Digor (Dolaylı) Kaya Resimleri”, XVIII. Türk Tarih Kongresi, (1-5 Ekim 2018 Ankara Baskıda). 
Ceylan, Alpaslan-Nezahat Ceylan, Doğunun Sönmeyen Nildızı Akçakale, Erzurum 2018.

Ceylan, Alpaslan - Özgül, Oktay, “Orta Asya'dan Anadolu'ya Türk Kültürünün Erken Dönem Şifreleri Kaya Resimleri”. 16. Uluslararası Türk Dünyası Sosyal Bilimler Kongresi / 04-06 Eylül 2018, İstanbul 2018, s. 68 - 69.

Ceylan, Alpaslan - Günaşdı, Yavuz, “Türk Bengütaş (Şiveet Ulan)'Daki Oğuz Damgaları İle Cunni Mağarasındaki Damga Ve İşaretlerin Karşılaştırılması”, Geçişten Günümüze Türkistan: Tarih, Kültür ve Medeniyet Sempozyumu, Kazakistan 2019, s. $62-80$.

Ceylan, Nezahat, "Yağlıca Kalesi’nde Yılan Figürü ve Türklerde Yılan Simgesi", Selçuk Üniversitesi Türkiyat Araştırmalan Dergisi S. 39, Konya 2016, s. 409-421.

Devlet, Ekaterina, "Rock Art Studies In Northern Russia And The Far East, 2000-2004", Rock Art Studies News World III, Ed. Paul Bahn - Natalie Franklin Matthias Strecker, Southhampton 2008.

Durmuş, İhami, “Orta Asya'dan Anadolu’ya Türk Konar- Göçer Kültürü”, Orta Asya Türk Kültürünün Anadolu Kültürüne Etkileri Uluslararast Sempozyumu (18-21 Haziran 2019 /Taşkent-Özbekistan), Ankara 2019, s. 11-35.

Esin ,Emel, "İslamiyet’ten Önceki Türk Kültür Tarihi ve İslama Giriş”, Türk Kültürü El Kitabr, Seri II, G I/b, İstanbul 1978.

Ferecova Melahat, Azerbaycan Qayaüstü İnceseneti, Bakü 2009.

Freh Wilhelm - Muvaffak Uyanık, "Hakkâri-Sat Dağlarında, Gevaruk Vadisi İçinde Bulunan Kaya Resimleri Hakkında Tebliğ", Belleten, C XXI/ S. 84, 1957, s. 619-625.

Günaşdı, Yavuz, "Doğu Anadolu Kaya Resimleri Işı̆̆ında Doyumlu Kaya Panoları”, Selçuk Üniversitesi Türkiyat Araştırmalan Dergisi, S. 39, Konya 2016, s. 391-407.

Hoppal, Mihaly, Şamanlar ve Semboller; Kaya Resmi ve Göstergebilim, çev. Fatih Sel, Istanbul 2015.

Karageçi, Mustafa, "Borluk Vadisi Erken Demirçağ Mezarı", Kafkas Üniversitesi Sosyal Bilimler Enstitüsü Dergisi, (Ek Sayı 1), 2016, s. 253-265.

Karpuz, Haşim, "Çamuşlu'da Yontma Taş Çağı Kaya Resimleri”, TÜBİTAK Bilim ve Teknik 10/212, Ankara 1977, s. 1-6. 
Khujanazarov, Muhiddin, "Rock Art Sites in Uzbekistan", Rock Art in Central Asia, Ed. J. Clottes, Paris 2011, s. 99-113.

Kökten, İ. Kılıç, "1952 Yılında Yaptı̆̆ım Tarih Öncesi Araştırmalar”, Dil Tarih ve Coğrafya Fakültesi Dergisi XI/S. 2-3-4, 1953, s. 177-209.

Kökten, İ. Kılıç, "Yazılıkaya'da ve Kurbanağa Mağarasında (Kars-Çamuşlu) Yeni Bulunan Dip Tarih Resimleri”, Karseli 6/69, Ankara 1970, s. 2-16.

Kubarev, Vladimir Dmitrievich -D.Tseveendorj-EstherJacobson Petroglyphes of Tsagaan-Salaa And Baga-Orgur Russia 2005

Kudret, İsmailzade, “Gobustan Açık Hava Müzesi”, IRS, 3(11), 2014, s. 6-11.

Ool, Çeçek Dolgar, Altay-Sayan Kaya Resimlerine Göre Tuva Geleneksel Kültürünün Kaynaklan, Kırgızistan-Türkiye Manas Üniversitesi, Sosyal Bilimler Enstitüsü, Yayımlanmamış Yüksek Lisans Tezi, Bişkek 2004.

Özgül, Oktay, "Erzurum Bölgesi Kaya Panoları", Trakya Üniversitesi Edebiyat Fakültesi Dergisi, 5(10), 2015, s. 169-198.

Özgül, Oktay, "Erzurum Şenkaya Petrogliflerindeki At Geyik ve Güneş Kursu", Selçuk Üniversitesi Türkiyat Araştırmalan Enstitüsü Dergisi (39), 2016, s. 371-390.

Özgül, Oktay -Nezahat Ceylan, "Eskiçağ’da Kafkasya Geçitleri (Daryal ve Derbent)", Akademik Tarih ve Düsünce Dergisi (4/13), 2017, s. 24-62.

Özgül, Oktay - Nezahat Ceylan, "Göçerlik ve Yerleşiklik Arasında Bir Bileşen: Fergana Vadisi”, Geçmişten Günümüze Türkistan: Tarih- Kültür Ve Medeniyet Sempozyumu, Ankara 2019, s. 472-496.

Özgül, Oktay -Burak Bingöl "Kuzeydoğu Anadolu Petrogliflerindeki Bir Grup Dağ Keçisi Motifi”, Art-Sanat, 16/2021, s. 491-529.

Ranov, Vadim, "Petroglyphs of Tadjikistan", Petroglyphs of Cenrtal Asia, Ed. K. Tashbayeva, 2001, s. 122-151.

Rogozhinskiy, Alexey E., "Rock Art Sites in Kazakhstan", Rock Art in Central Asia, Ed. J. Clottes, Paris 2011, s. 9-43.

Somuncuoğlu, Servet, Sibirya'dan Anadolu'ya Taştaki Türkler, İstanbul 2008.

Somuncuoğlu, Servet, Saymahttaş: Gökyüzü Atlan, İstanbul 2011.

Tashbayeva, K., "Petroglyphs of Kyrgyzstan", Petroglyphs of Central Asia, Bishkek 2001. 
Tepfer, E. Jacobson, The Life of Two Valleys in the Bronze Age. Rock Art in the Mongolian Altai, Luminaire Press, 2019.

Tokarska, Malgorzata - Cino, Pertoldi - Rafal, Kowalczyk - Kajetan, Perzanowski, "Genetic Status of the bison Bison bonasus after extinction in the wild and subsequent recovery", Mammal Review, 2011, s. 1-12.

Tokhatyan, Karen, "Rock Carvings Of Armenia", Fundamental Armenology No 2, 2015, s. 184-204.

Tümer, Hale, Van-Hakkâri Dağlk Bölgesi Kaya Resimleri, (Yayımlanmamış Yüksek Lisans Tezi), İstanbul Üniversitesi Sosyal Bilimler Enstitüsü, İstanbul 2017.

Uyanık, Muvaffak, "Van-Hakkâri Sınırında Tırşin Yaylasında Bulunan Kaya Resimleri Hakkında", Belleten, C XXXII/S. 125 1968, s. 97-103.

Uyanık, Muvaffak, Petroglyphs of South - Eastern Anatolia, Akademische Druck und Verlagsanstalt, Graz 1974.

Üngör, İbrahim, “Orta Asya'dan Anadolu'ya Kayalara Yazllan Türk Kültürü (Dereiçi Kaya Resimleri)", Selçuk Üniversitesi Türkiyat Araştırmalan Dergisi 39, 2016, s. $357-370$.

Üngör, İbrahim, "Türk Kültüründe Dağ Keçisi/Teke Ve Doğu Anadolu Petrogliflerinde Bulunan Dağ Keçisi/Teke Figürleri Üzerine Görüşler" IV Uluslararası Türk Ş̈̈leni Türk Kültürü Sempozyumu Bildirileri Erzurum 2018, s. 326-345.

Xelilov, T., Gemigaya Etrafinda Aexeoloji Tedgigatlan, Nahcivan 2018.

Yıldırım, Elvin, "Büyük ve Küçük Bayar Kaya resimleri”, Türk Dïnyası Araştırmalarn Vakfi, C. 62/S. 372, 2017 s. 34-38.

Yılmaz, Anıl, "Saymalıtaş Petrogliflerindeki Toy (Şenlik) Sahneleri Üzerine”, Tarih İncelemeleri Dergisi, XXVIII/1, İzmir 2013, s. 223-248.

http://www.patikaa.com/anadolu-ve-kafkas-cografyasinda-bulunan-en-eski-petroglif/ (12.04.2020) 